\title{
Genomic Comparisons of Two Armillaria Species with Different Ecological Behaviors and Their Associated Soil Microbial Communities
}

\author{
Jorge Ibarra Caballero
}

Colorado State University

Bradley M Lalande

Colorado State University

John W Hanna

Rocky Mountain Research Station

Ned B Klopfenstein

Rocky Mountain Research Station

\section{Mee-Sook Kim}

Pacific Northwest Research Station

Jane E Stewart ( $\square$ Jane.Stewart@colostate.edu )

Colorado State University https://orcid.org/0000-0001-9496-6540

\section{Research Article}

Keywords: Armillaria root disease, tree health, genomes, pathogenic, beneficial fungi, dybiosis

Posted Date: October 18th, 2021

DOI: https://doi.org/10.21203/rs.3.rs-969366/v1

License: (1) This work is licensed under a Creative Commons Attribution 4.0 International License.

Read Full License

Version of Record: A version of this preprint was published at Microbial Ecology on March 21st, 2022. See the published version at https://doi.org/10.1007/s00248-022-01989-8. 


\section{Abstract}

Armillaria species show considerable variation in ecological roles and virulence, from mycorrhizae and saprophytes to important root pathogens of trees and horticultural crops. We studied two Armillaria species that can be found in coniferous forests of northwestern USA and southwestern Canada. Armillaria altimontana is considered as a weak, opportunistic pathogen of coniferous trees, but it also appears to exhibit in situ biological control against $A$. solidipes, formerly North American A. ostoyae, which is considered a virulent pathogen of coniferous trees. Here, we describe their genome assemblies and present a functional annotation of the predicted genes and proteins for the two Armillaria species that exhibit contrasting ecological roles. In addition, the soil microbial communities were examined in association with the two Armillaria species within a 45-year-old plantation of western white pine (Pinus monticola) in northern Idaho, USA, where $A$. altimontana was associated with improved tree growth and survival, while $A$. solidipes was associated with reduced growth and survival.

\section{Introduction}

In recent decades, the genetics of fungal pathogenicity and symbioses have been studied in concert to identify potential patterns related to divergent ecological roles. Genomic comparisons among pathogenic and symbiotic fungi have highlighted great diversity in gene content, genome size, repeat content, and number of chromosomes among fungi with distinct ecological roles [e.g., 1, 2].

Within the Agaricales of basidiomycota, 13,000 species have been described and lifestyles among these range from saprophytes to pathogens to ectomycorrhizal symbionts [3]. Evolutionary studies suggest that ectomycorrhizal lifestyle likely arose from saprophytic fungi [4]. Historically, ectomycorrhizal (ECM) fungi were thought to have reduced numbers of genes encoding plant cell wall-degrading enzymes (PCWDEs), including carbohydrate degrading enzymes. Recent literature has suggested that ECM fungi contain diverse repertoires of these genes encoding PCWDEs [5]. ECM fungi typically retain the distinct suites of PCWDEs and Carbohydrate-Active Enzymes (CAZymes) of their saprotrophic ancestors; some, like the fungal CAZymes acting on pectin (GH28, GH88 and CE8), are expressed in ECM fungi on ectomycorrhizal root tips [5]. Further, little evidence suggests that common gene repertoires exist among ECM fungi [1]. The genome of Laccaria bicolor, a well-described ECM fungus, contained twice as many secreted CAZymes [Glycoside-Hydrolases (GH), Polysaccharide Lyases (PL), and Carbohydrate Esterases (C)] than polysaccharide biosynthetic and modifying enzymes [6]; however, this pattern was also observed in the forest root pathogen, Heterobasidion annosum [7, 8]. Similarly, both mutualistic and parasitic species of Agaricomycotina typically have an abundance of transposable elements [9]. Thus, differences in genomic content of Agaricales fungi with divergent lifestyles are difficult to detect.

The genus Armillaria (Basidiomycota, Agaricales) includes several important plant pathogens of trees/woody plants, but also includes species that are symbionts or even hosts of other organisms [1012]. Armillaria species are also important decomposers in the forests where they occur, especially because they can degrade lignin [11]. Among Armillaria species, A. solidipes (formerly North American A. 
ostoyae) is considered one of the more virulent pathogens [13], although virulence varies depending on isolate, host age and other factors [14]. Armillaria mellea and A. borealis are also considered virulent pathogens, while A. gallica, A. cepistipes, A. gemina, A. calvescens, A. sinapina, and A. nabsnona are considered less virulent or secondary pathogens $[10,12,15,16]$. A recently described species, Armillaria altimontana, formerly North American biological species (NABS) $X$, is also usually considered as a weak pathogen [17], but evidence for pathogenicity is not well documented [18].

Armillaria solidipes (as A. ostoyae) and A. altimontana have been documented to co-occur within forest stands in the inland northwestern USA [18-20]. A previous study in northern Idaho, USA provided evidence that $A$. altimontana can provide natural biological control of Armillaria root disease of western white pine (Pinus monticola) caused by A. solidipes. In this study, A. solidipes was uncommon in areas dominated by $A$. altimontana, and trees colonized by $A$. solidipes were associated with a lower growth and survival than trees colonized only by $A$. altimontana. The results demonstrated that $A$. altimontana was not harmful to western white pine within the northern Idaho planting site, and further suggest that $A$. altimontana behaves as a long-term, in situ biological control agent against $A$. solidipes [20]. Recognizing the genetic or underlying soil factors that drive host-fungal interactions may provide approaches for enhancing the management of Armillaria root disease.

The distribution, life cycle, pathogenicity, and evolutionary relationships have been studied for several Armillaria species [10, 12, 14, 16, 21-25]. Collins et al. [26] studied the genome and proteome of $A$. mellea, identifying carbohydrate degrading enzymes, laccases, and lignin peroxidases among other geneencoded proteins. Ross-Davis et al. [27] characterized the transcriptome of an A. solidipes mycelial fan infecting grand fir (Abies grandis), finding high expression of transcripts coding for PCWDEs, along with enzymes and $A B C$ transporters that may help detoxify host-produced defense compounds. More recently, genomes of four Armillaria species (A. cepistipes, A. gallica, A. ostoyae, and A. solidipes) were sequenced by Sipos et al. [28]; this comparative genomic study revealed a rich repertoire of PCWDEs and pathogenicity-related genes in these Armillaria species regardless of their ecological behaviors. This study also identified expression of numerous pathogenicity-related transcripts and proteins during fruiting body and rhizomorph development $[24,28]$.

Assessing interactions among the soil fungi with different ecological lifestyles (e.g., saprophytes, pathogens, mycorrhizal symbionts, etc.) within the microbial communities is critical to understand disease development. As a well-known example, the association between mycorrhizal fungi and roots that form mycorrhizae allow for increased water and nutrient uptake that sustain tree health [29-33]. Microbes also breakdown litter and forest debris, which maintains forest health by improving soil quality and recycling nutrients that are required by plants [34-38]. In addition, pathogenic soil fungi function as selective agents that can cause mortality to maladapted trees, increasing the vigor and relative adaptation of residual trees in a stand [39-41]. In contrast, highly virulent soil pathogens can infect healthy tree roots, resulting in tree mortality that ultimately degrades the health of forest stands [41]. Additionally, the ability to favor beneficial microbes that inhibit root pathogens, which are notoriously difficult to mitigate, may enhance current management techniques [42, 43]. 
Soil metagenomics or metabarcoding can be used to identify important fungi, bacteria, and archaea associated with tree health [43]. Determinations of the soil microflora can allow evaluations of treatment (e.g., soil amendments, forest thinning, underburning) influences on naturally occurring microbial communities that favor or suppress forest root diseases/pathogens, which could provide new approaches to manage Armillaria root disease $[20,44,45]$.

We present the genome assembly and annotation of the potentially beneficial $A$. altimontana isolated from northern Idaho, northwestern USA, and compare it with the genome of a pathogenic $A$. solidipes isolated from the same region. We also compare the fungal and bacterial communities in the soil associated with two Armillaria species - A. altimontana and A. solidipes. Putative secreted and nonsecreted proteins encoded in each of the Armillaria genomes and the potential relationship with associated microbial communities are described, with emphasis on genes related to pathogenicity and fungal lifestyles. The data presented here contribute to understanding the ecological function of Armillaria species at the genomic level and will serve as resources for understanding genetic and ecological functions of these and other soil fungi.

\section{Materials And Methods}

Biological isolates for the genome sequencing. Armillaria solidipes [isolate ID001; 27] was obtained from a culture of a basidiospore derived from a fruiting body belonging to a genet that was causing disease via an active mycelial fan growing below the bark of a live grand fir at the Clearwater National Forest, ID, USA. Armillaria altimontana (isolate 837-10) was obtained from a basidiospore from a fruiting body collected from the forest soil, with no host tree association ca. $2 \mathrm{~km}$ from the same location. Haploid, basidiospore-derived cultures were established for both species.

DNA isolation. Isolates of $A$. solidipes and $A$. altimontana were grown for 3-4 weeks on $0.22 \mu \mathrm{m}$-pore MFMillipore ${ }^{\mathrm{TM}}$ Membrane nylon filters (MilliporeSigma, Burlington, MA) over half-strength "Armillaria" culture medium: $1.5 \%$ malt extract, $1.5 \%$ glucose, $0.5 \%$ peptone, $1.2 \%$ agar. The fresh mycelia (ca. $1-2 \mathrm{~g}$ ) was ground by mortar and pestle with liquid nitrogen, and the DNA was extracted with the MoBio (Qiagen) DNeasy PowerMax Soil Kit (Cat.\# 12988), following the protocol of the manufacturer.

Genome sequencing and assembly. PacBio sequencing and assembly of the two Armillaria species genomes were performed at the Laboratory for Biotechnology and Bioanalysis (LBB), Washington State University. Briefly, 10-15 $\mu \mathrm{g}$ of DNA was sheared using Covaris g-Tubes for 10 minutes at 1,350xg in a Minifuge 16 centrifuge (Beckman Coulter). Approximately, $5 \mu \mathrm{g}$ of sheared DNA was processed for Pacific Biosciences SMRT bell libraries preparation following the "Procedure and Checklist-20 kb Template Preparation using BluePippin Size Selection System" (P/N 100-286-000-5) protocol (Pacific Biosciences) and the Pacific Biosciences SMRTbell Template Prep kit 1.0 (P/N 100-259-100). Resulting SMRTbell libraries were size selected using a BluePippin gel purification system (Sage Biosciences) according to the Blue Pippin User Manual and Quick Guide. The $0.75 \%$ agarose gel cassette was used with a cut-off limit set to $15 \mathrm{~kb}-50 \mathrm{~kb}$. The resulting SMRTbell library molecules had an average size of approximately 
$\geq 18 \mathrm{~kb}$. Appropriate concentrations for the annealing and binding of the SMRTbell libraries were determined using the Pacific Biosciences Binding and Annealing calculator. SMRTbell libraries were annealed and bound to the P6 DNA polymerase for sequencing using the DNA/Polymerase Binding Kit P6 v2.0 (P/N100-372-700), following the recommended protocol from Pacific Biosciences but extending the binding times to 1-3 hours, compared to suggested 30 minutes. The bound SMRTbell libraries were loaded onto the SMRT cells using the standard MagBead protocol, and the MagBead Buffer Kit v2.0 (P/N 100-642-800). Then, the standard MagBead sequencing protocol was followed using the DNA Sequencing Kit 4.0 v2 (P/N 100-612-400) (typically known as P6/C4 chemistry). Sequencing data were collected for 6-hour movie times and Stage Start was enabled to capture the longest single reads possible. Genome assemblies were performed within the Pacific Biosciences SMRT Portal software. HGAPII was used following standard defaults for genome assembly.

Genome assembly and evaluation. Metrics for the genome assemblies, including scaffolds number, total length, GC content, and N50, were obtained using the QUAST [46] web server. Completeness of the assemblies was evaluated using BUSCO 2.0b2 [47]. BUSCO utilizes sets of genes present as single-copy orthologous in a number of species within a clade. For the evaluation of the Armillaria genome assemblies, the "Fungi dataset" and the "Basidiomycota dataset" were used. The default e-value of 0.001 was kept for the BLAST searches.

Phylogenetic tree analysis. Whole genome phylogenetic tree was created using Realphy 1.12 [48] with Bowtie2 2.3.3.1 [49] for read mapping and PhyML [50] to build the tree. Preset options were used to run the Realphy pipeline. Whole genome assemblies of Armillaria species available at the National Center for Biotechnology Information or the Join Genome Institute websites and the two genome assemblies described in this work were included. The number of bootstrap replicates in PhyML was set to 200 .

Structural and functional genome annotations. A set of repetitive sequences was obtained for each of the genome assemblies of $A$. solidipes and $A$. altimontana using RepeatModeler v.1.0.11 [51]. As the first step in the Maker v.2.31.8 pipeline [52], repetitive sequences files were used by RepeatMasker v.4.0.6 [53], to mask and obtain descriptions of interspersed repeats and low complexity DNA sequences. Next, the gene predictors Augustus [54]. GeneMark-ES [55], and SNAP [56] were used for gene prediction in Maker. TRNAscan-SE [57] was also included to predict tRNA genes. For Augustus, a closely related species, Coprinus cinereus, was used as species model. SNAP was trained with a set of protein-encoding sequences from Armillaria species and closely related species, obtained from the NCBI and EnsemblFungi databases.

The set of proteins generated by Maker was functionally annotated using BLASTp v.2.9.0+ [58] and InterProScan v.5.20-59.0 [59]. Only proteins $\geq 50$ amino acids were considered for these and further annotation analyses. For the BLAST search, a database was built with all entries for fungi in the UniProtKB database. A maximum e-value of 0.001 was used. For the InterProScan analysis, the Pfam application was included. Results from BLAST and InterProScan were added to the structural annotation in new gff3 files. 
CAZymes were also annotated using the dbCAN2 server [60]; proteins involved in pathogenicity were searched using BLASTp at the PHI database version 46 [61]. Secondary metabolite clusters were annotated using antiSMASH server version 5.1.2 [62] with the detection strictness set to strict, including for the analysis the corresponding genome FASTA file of $A$. altimontana and A. solidipes. Deeploc 1.0, a program that utilizes deep learning algorithms [63], was used to predict the set of secreted proteins.

Structural annotation evaluations. Completeness of the Armillaria proteomes generated by Maker was evaluated using BUSCO 2.0b2. The "Fungi dataset" and the "Basidiomycota dataset" were used as assessed for the genome assemblies. The default e-value of 0.001 was also kept for the BLAST searches.

Synteny analysis and visualization. Analysis and graphs of synteny blocks (i.e., genomic regions of conserved gene content) were made using SyMAP $2.4[64,65]$. Genome assemblies and GFF3 files produced by Maker were used to obtain the synteny graphs. Default parameters were used to run the program, except the minimum sequence size was set to 10,000 bp.

Analysis of orthologous protein families. The set of predicted proteins generated by Maker for $A$. altimontana and $A$. solidipes were used to identify orthologous and species-exclusive (non-orthologous) groups using the OrthoVenn2 web server [66]. Two parameters can be adjusted when using the OrthoVenn2 web server: e-value and inflation value; they were set to $1 \mathrm{e}-10$ and 2 , respectively. These values were chosen to slightly increase the detection of more non-orthologous proteins compared to the default values (1e-2 and 1.5 respectively).

Study area and field sampling for soil microbial analysis. The study area was located in northern Idaho at the USDA, Forest Service Priest River, Experimental Forest (Supplemental Figure 1). The field site was a historic western white pine seed provenance plot within the Ida Creek study area (ca. $48^{\circ} 21 \varangle 48.75 \square \mathrm{N}$ and $116^{\circ} 49 \otimes 25.36 \rrbracket$ W, elevation ca. 770 m.a.s.I.). In 1971, 2,372 seedlings from Idaho and Washington were planted in a common garden plantation [20]. In 1987, all 2,076 remaining trees were sampled for diameter at breast height $(\mathrm{DBH})$, height, tree health status and association with $A$. solidipes and $A$. altimontana, as described by Warwell et al. [20].

In 2016, 60 trees were randomly selected for sampling, ensuring that half of the trees were historically associated with either $A$. solidipes or $A$. altimontana. Three additional trees (ca. 63) were sampled with needle discoloration and the formation of mycelial fans on the base of the trunk, indicating the presence of $A$. solidipes. Tree measurements included $\mathrm{DBH}$ and tree health status, which was based on total amount of needles, color of foliage, insect and disease presence, and dead/live status.

For soil sampling, $1 \mathrm{~m}$ from the main stem of a tree near root zones, depths of duff and litter were measured at each cardinal direction in a $30-\mathrm{cm}$ diameter circle. The area was then cleared, and bulk soil samples were taken for each of the 63 trees using a 15-cm, split soil corer with a 15.9-mm (5/8 inch), compact slide hammer (AMS, \#400.99, American Falls, ID). Samples were homogenized, $2 \mathrm{~g}$ were placed in a $15 \mathrm{ml}$ tube with $5 \mathrm{ml}$ of LifeGuard RNA preservation solution (Qiagen ${ }^{\circledR}$, Carlsbad, CA), and samples were placed on ice for preservation until storage. Samples were stored at -80C prior to DNA extractions. 
Remaining bulk soils from each tree were sent to the USDA Forest Service, Rocky Mountain Research Station, Soils Laboratory in Moscow, ID for soil characteristics measurements and chemistry calculations.

Armillaria rhizomorphs adjacent to the roots were also excavated using a small Pulaski-like gardening tool and brushes. Primary rhizomorph collections occurred on the same side as the soil core while an additional sample was collected $180^{\circ}$ on the opposite side of the tree from the core. Rhizomorphs were placed in $15 \mathrm{ml}$ tubes and placed on ice or $4^{\circ} \mathrm{C}$ until isolation and culture.

Armillaria isolation, DNA extractions and PCR. Rhizomorphs were plated for fungal isolation within 7 days of collection. Each rhizomorph was surface sterilized by an initial rinse with sterile-distilled water to remove the attached soil particles, followed by a soak in $20 \%$ Clorox ${ }^{\circledR}$ bleach solution (1.5\% sodium hypochlorite, final concentration) for 6-10 minutes, a rinse with sterile-distilled water and a soak in 3\% hydrogen peroxide for 6-10 minutes. After a final rinse with sterile-distilled water, small rhizomorph sections (ca. $1-\mathrm{cm}$ ) were plated onto Armillaria culture media (3\% malt extract, $3 \%$ dextrose, $1.5 \%$ peptone, $1.5 \%$ agar) and incubated at $22^{\circ} \mathrm{C}$ in the dark to promote mycelial growth.

For DNA extractions from Armillaria cultures, mycelia were sub-cultured onto Millipore ${ }^{\mathrm{TM}}$ Membrane nylon filters that overlaid "Armillaria" culture medium. After 2-3 weeks, mycelia were scraped off the nylon filters, and DNA was extracted from $>50 \mathrm{mg}$ of mycelia using Zymo Fungal/Bacterial DNA extraction kits (Irvine, CA), following manufacturer protocols with a few modifications. To maximize DNA quantity and quality, three 3-mm glass beads were added to the cell lysis step prior to homogenization (Thermo Savant FastPrep ® FP120 Cell Homogenizer; Qbiogene, Carlsbad, CA) at 6.0 speed with two 30-second cycles. DNA concentration and quality were quantified using a NanoDrop ${ }^{T M} 2000$ spectrophotometer (Thermo Fisher Scientific, Wilmington, DE).

For species identification, DNA was amplified at the translation elongation factor-1a (tef1) locus using primers EF-983 and EF-2218 [67] with an Eppendorf Mastercycler pro Thermal Cycler (Eppendorf, Hamburg, Germany). The PCR cycle was $94^{\circ} \mathrm{C}$ for 2.5 minutes, 30 cycles of $94^{\circ} \mathrm{C}$ for 30 seconds, $60^{\circ} \mathrm{C}$ for 30 seconds, and $72^{\circ} \mathrm{C}$ for 1.5 minutes, with a final cycle at $72^{\circ} \mathrm{C}$ for 10 minutes. PCR products were visualized using gel electrophoresis, cleaned with ExoSAP-IT TM PCR Product Cleanup Reagent (Thermo Fisher Scientific, Santa Clara, CA), and then Sanger sequenced in two directions by Eurofins Genomics (Louisville, KY). Sequences were edited and aligned in Geneious R11.1 (https://www.geneious.com). Aligned sequences were identified by comparing to the NCBI (National Center for Biotechnology Information) database using BLASTn (https://blast.ncbi.nlm.nih.gov/Blast.cgi) [58].

Soil DNA extraction protocol and sequencing. DNA was extracted from the soil samples preserved in LifeGuard $^{\text {TM }}$ Preservation Solution using MoBio Powersoil Total RNA Isolation and DNA Elution Accessory kits (Qiagen ${ }^{\circledR}$, Carlsbad, CA), following manufacturer protocols. The $15-\mathrm{mL}$, bead tubes with soil were centrifuged for 5 minutes to separate the soil in the LifeGuard ${ }^{\text {TM }}$ Preservation Solution. The LifeGuard ${ }^{\text {TM }}$ Preservation Solution was pipetted from the tubes and discarded to leave just the soil. The complete 
MoBio Powersoil $\circledast$ manufacturer protocols were followed, resulting in $100 \mu \mathrm{L}$ of eluted DNA for each sample. DNA qualification and quality were measured using a Nanodrop ${ }^{\mathrm{TM}} 2000$ spectrophotometer.

Soil DNA $(30 \mu \mathrm{L})$ was sent to the University of Minnesota Genomics Center and Colorado State University Next-Generation Sequence (NGS) lab for library preparation and sequencing on an Illumina MiSeq and paired-end $2 \times 250$ reads were generated. A total of 57 out 63 samples were sent for sequencing; the six remaining samples were excluded because they did not yield sufficient DNA concentration/quality. Libraries were prepared for the internal transcribed spacer (ITS2) region to sequence fungal communities and the $v 4$ genomic region of the $16 \mathrm{~S}$ rRNA to sequence bacterial communities. Primers ITS3 (5'GCATCGATGAAGAACGAGC-3') and ITS4 (5'TCCTCCGCTTATTGATATGC-3') [68] were used to amplify the ITS2 region, and primers 515F (5'-GTGCCAGCMGCCGCGGTAA-3') and 806R (5'GGACTACHVHHHTWTCTAAT-3') [69] were used to amplify the v4 region of the 16S rRNA. DNA-free samples were included as negative controls to verify lack of microbial or DNA contamination in the buffers and primer sets. These sequence data have been submitted to the NCBI SRA database under accession number PRJNA767898.

Cleaning DNA sequence data. Data were cleaned to ensure base-calling accuracy of $\geq 99.9 \%$ using the paired end mode in the program Trimmomatic v0.36 [70]. Sequences $\leq 100 \mathrm{bp}$ in length, low quality bases scores $(\leq 15)$, and $4 \mathrm{bp}$ sliding window regions with low average quality scores $(\leq 25)$ were removed from the data set. The software Mothur v1.40.5 [71] was implemented utilizing the Standard Operating Procedure [72], with some adjustments, to call operational taxonomic units (OTUs) and classification of taxa. Following adjustments described in the SOP (https://github.com/Abdo-Lab/Microbiome-AnalysisScripts/blob/master/PE-de-novo-processing.pl), UCHIME [73] was used to de novo identify and remove de novo chimeric sequences, and USEARCH [74], utilizing the dgc (distance-based greedy clustering) option, was used for clustering. Groups that were at least $97 \%$ similar were classified as belonging to the same OTU. Sequences associated with chloroplast, mitochondria, archaea, and bacteria lineages were removed from the table of classified sequences. We utilized the 128 Silva database [75] and the UNITEv6_sh_dynamic_s [76] databases for bacterial and fungal taxonomic classifications, respectively, using Wang's Naïve Bayes classifier with a cutoff value of 80 [77]. Rarefaction curves were generated using the package 'vegan' as implemented in R version 3.6.1 to assess diversity and suitability of depth of coverage per sample [78].

Statistical analysis of communities. Using the RStudio interface to R (R Core Team 2017), alpha diversity, including Shannon diversity index and Inverse Simpson were calculated using phyloseq [79] and rarefied richness (Richness) was determined in Vegan. Shannon's index was used to determine diversity utilizing the relationship to richness and rare microbes $[80,81]$. Inverse Simpson was used to identify diversity based on evenness and more dominant microbes to identify diversity [81]. Richness was considered as the number of individuals identified within a single sample, while evenness was used to explain the relative abundance of the different individuals [82]. 
The relative abundance of taxa associated with $A$. solidipes-and $A$. altimontana-associated soils was determined for the top fungal and bacteria taxa using a stacked bar graph with the metagenomeseq package in $\mathrm{R}$ [83]. Differences among communities associated with Armillaria species were assessed using a PERMANOVA. Principle component analysis plots were completed in vegan to visualize fungal and bacterial soil differences associated with each Armillaria species.

Utilizing relative abundance data based on the resulting OTU table, bar graphs were generated using the ggplot2 package [84] in $\mathrm{R}$ for observed taxa with relative abundance $>1 \%$ at the genus level to describe the microbial community structure associated with each Armillaria species. The MetagenomeSeq package [83] in R was used to fit a model that identified those OTUs associated with significance of model fit at a 0.01 level and minimum fold change of 2 ( $p$ values were adjusted for multiple testing). This was used to identify the driver of OTU differences between treatments and time points. Core fungal and bacterial communities were created for each Armillaria species. Counts were calculated in R to assess the presence of an OTU corresponding to each species of Armillaria. Venn diagrams were produced using molbiotools.com to identify unique and shared fungal and bacterial taxa associated with $A$. solidipes and A. altimontana.

To identify influences of what soil chemistry properties on soil fungal communities, a PERMANOVA analysis was completed using the vegan package in $\mathrm{R}$. The analysis identified significant predictors by completing a forward stepwise analysis based on the subset of variables that minimized the Akaike Information Criterion (AIC).

\section{Results}

Genome assemblies of A. solidipes and A. altimontana. The PacBio assemblies resulted in a 73,739,702 bases genome for $A$. altimontana isolate $837-10$ and a 55,735,298 bp genome for $A$. solidipes isolate ID001; both isolates originated near Elk River, Idaho, USA (Table 1). The ratio of genomes sizes, $A$. altimontana / $A$. solidipes $=1.32$, is consistent with the ratio of the reported DNA content per nucleus of these two species, 1.34 [19]. The corresponding genome assemblies were deposited at the NCBI with accession number JAIWYR000000000 for $A$. altimontana, and JAIWYQ000000000 for $A$. solidipes. 
Table 1

Genome asssembly metrics for Armillaria altimontana and $A$. solidipes.

\begin{tabular}{|lll|}
\hline Feature & A. altimontana & A. solidipes \\
\hline \# scaffolds & 100 & 72 \\
\hline Total length & $73,739,702$ & $55,735,298$ \\
\hline Largest contig & $5,843,527$ & $4,463,803$ \\
\hline GC (\%) & 47.77 & 48.26 \\
\hline N50 & $1,930,169$ & $2,424,439$ \\
\hline
\end{tabular}

In a whole-genome phylogenetic tree, two A. solidipes isolates from North America, ID001and 28-4, group together (Figure 1), apart from but close to isolate $\mathrm{C} 18 / 9$ of $A$. ostoyae from Europe [28]. Figure 1 also shows the position of $A$. altimontana with respect to $A$. solidipes and other Armillaria species. Armillaria altimontana is contained within a clade comprising $A$. cepistipes B5 and $A$. gallica Ar21-2, which is distinct from the $A$. solidipes/ostoyae clade.

After a custom library of repeats obtained using RepeatModeler was input to RepeatMasker, more bases in A. altimontana (18,346,415 bp) were masked compared to those in A. solidipes (9,691,790 bp). When comparing $A$. altimontana to $A$. solidipes, the relative proportion of masked bases (1.89) was larger than the ratio of their genome sizes (1.32). The percentage of genomic sequences occupied by interspersed repeats and low complexity DNA regions for $A$. altimontana and $A$. solidipes were $24.88 \%$ and $17.39 \%$, respectively (Supplemental Table 1); the largest percentages corresponded to retrotransposons. The most abundant retrotransposons were Long Terminal Repeats (LTRs) as is common in other fungi [85].

Completeness of the genome assemblies was assessed using BUSCO using datasets for both the fungal and basidiomycota lineages. The $A$. altimontana genome assemblywas $95.1 \%$ complete when compared to the fungal dataset, and $96.7 \%$ when compared to the Basidiomycota dataset. The completeness values for $A$. solidipes were similar at $95.9 \%$ and $96 \%$, respectively, and similar to that reported for other Armillaria species [28], which indicates high quality for genome assemblies.

Large blocks of shared synteny were found when comparing the $A$. altimontana and $A$. solidipes genomes (Figure 2A shows the 20 largest scaffolds of each species), especially for some of the largest scaffolds of each species (Figures 2B-G). For example, most of $A$. altimontana scaffold 1 (5,843,527 bp) shared synteny with blocks in two $A$. solidipes scaffolds ( 1 and 2, Figure $2 \mathrm{~B}$ ), most of $A$. altimontana scaffold 2 (5,540,602 bp) shared synteny with blocks in three $A$. solidipes scaffolds $(10,14$, and 18 , Figure 2C), and most of $A$. altimontana scaffold $3(4,489,203 \mathrm{bp})$ shared synteny with blocks in two $A$. solidipes scaffolds (7 and 11, Figure 2D). Likewise, most of $A$. solidipes scaffold 1 (4,463,803 bp) shared synteny with blocks in three $A$. altimontana scaffolds (1, 9, and 13 , Figure $2 \mathrm{E})$; most of $A$. solidipes scaffold $2(4,456,508$ bp) shared synteny with blocks in two $A$. altimontana scaffolds (1 and 14, Figure 
$2 \mathrm{~F})$; and most of $A$. solidipes scaffold $3(4,392,256 \mathrm{bp})$ shared synteny with blocks in four $A$. altimontana scaffolds $(8,17,18$, and 37 , Figure $2 G)$. A number of other smaller complete scaffolds of each species also shared synteny with blocks in one or more scaffolds of the other species (Figure 2A).

Structural and functional annotation. The Maker annotation pipeline predicted several features for the genome assemblies, including CDs, exons, 5'-UTRs, genes, mRNAs, 3'-UTRs, and tRNAs, which were organized in GFF3 files (Table 2; Supplementary Files 1 and 2). High similarity was observed between the genomes of $A$. altimontana and $A$. solidipes. More protein-coding genes were present in the $A$.

altimontana genome $(19,130$ versus 16,105$)$, although the ratio of protein-coding genes, 1.18 , is a little smaller than the ratio of genomes sizes (1.32). Despite its smaller genome, the $A$. solidipes genome contained more tRNAs genes (315 versus 280) (Table 2).

Table 2

Genome features of Armillaria altimontana and A. solidipes

\begin{tabular}{|lll|}
\hline Feature & A. altimontana & A. solidipes \\
\hline Genes & 19,326 & 16,357 \\
\hline Average gene length (bp) & 1,504 & 1,563 \\
\hline Gene density (genes per Mb) & 262 & 293 \\
\hline Average exons per gene & 5.2 & 5.6 \\
\hline Average exon length (bp) & 219.8 & 217.2 \\
\hline Average introns per gene & 4.2 & 4.6 \\
\hline Average intron length (bp) & 85.9 & 75.3 \\
\hline tRNA genes & 280 & 315 \\
\hline transcripts/proteins* & 19,130 & 16,105 \\
\hline * some genes are predicted to code for more than one protein \\
\hline
\end{tabular}

Completeness of the predicted proteomes was assessed using BUSCO, again with datasets for both the fungal and Basidiomycota lineages. For $A$. altimontana, proteome completeness was $96.9 \%$ when compared to the fungal dataset, and $96.4 \%$ when compared to the Basidiomycota dataset. Proteome completeness values for $A$. solidipes were $97.2 \%$ and $96.7 \%$, respectively, indicating high quality of the genome structural annotations.

Predicted proteins sets for $A$. altimontana and $A$. solidipes (Supplementary Files 3 and 4 ) were functionally annotated using BLASTp against all the fungi entries in the Uniprot database, and by using InterProScan including the Pfam application. These results were added to the final genome models produced by Maker, in GFF3 format (Supplementary Files 1 and 2). For $A$. altimontana, 17,997 encoded proteins had a BLASTp hit, and 8,483 had an InterProScan (Pfam) hit ( $94.0 \%$ and $44.3 \%$ of the total, 
respectively). For $A$. solidipes, 15,449 encoded proteins had a BLASTp hit, and 8,132 had an InterProScan (Pfam) hit (95.9\% and $50.4 \%$ of the total, respectively).

In comparisons with other Armillaria proteomes, 9,061 A. altimontana isolate-encoded proteins had a BLASTp hit to A. gallica proteins, 4,723 to A. ostoyae proteins, and 3,906 to A. solidipes proteins $(8,629$ to A. ostoyae/ solidipes proteins) (Supplementary Files 3 and 4). For our $A$. solidipes isolate-encoded proteins, only 1,321 had a BLASTp hit to A. gallica proteins, 6,665 to A. ostoyae proteins, and 7,300 to other $A$. solidipes proteins ( 13,795 to $A$. ostoyae/ solidipes proteins).

Secreted proteins. The program Deeploc was used to obtain corresponding sets of putative secreted proteins of $A$. altimontana and $A$. solidipes to search for differences that might reflect the lifestyle differences. A total of 1,235 ( $6.4 \%$ of the total) secreted proteins were predicted in A. altimontana and 1,157 (7.1\%) were predicted in A. solidipes. In A. altimontana, 322 secreted proteins had a CAZyme annotation; and 2 were cytochrome P450; in A. solidipes, the number of hits in each category were similar: 316 as CAZYmes; and 3 were cytochrome P450. No secreted proteins from either species had a blast hit with identity above $95 \%$ to proteins in the PHI database (data not shown). Some of the proteins had a CAZyme and a BLASTp hit, with one or several hits in the InterProScan search. But 99 secreted proteins in A. altimontana produced no hits and other 436 produced only BLASTp hits to uncharacterized proteins; in A. solidipes, 69 secreted proteins produced no hits and other 421 produced only BLASTp hits to uncharacterized proteins. However, many of these uncharacterized proteins could be considered "small secreted proteins" (see below). All those different annotations were combined and manually curated (Supplemental Files 3 and 4).

Numbers of secreted proteins with putative involvement in pathogenicity were obtained for each Armillaria species. The differences between the two species were small (Supplemental Figure 2); the two major differences were a higher number of peptidases secreted by $A$. solidipes and a higher number of small secreted proteins for $A$. altimontana.

When grouped by probable function (Figure 3), the major differences in predicted secreted proteins of $A$. altimontana and $A$. solidipes were associated with cell wall-degrading enzymes. Armillaria solidipes showed a slightly larger number of enzymes that degrade plant cell wall components: cellulose, hemicellulose, lignin, and especially pectin. Encoded-protein degrading enzymes also were more abundant in A. solidipes compared to A. altimontana (Figure 3). Abundances of other encoded protein categories showed smaller differences.

The number of encoded proteins that could be considered "small secreted proteins", defined as those smaller than 300 amino acids (after being predicted as "extracellular"), were 678 ( $55 \%$ of total secreted) in A. altimontana, 381 with at least $2 \%$ cysteine residues; and 594 ( $\sim 51 \%$ of total secreted) in A. solidipes, 334 with at least $2 \%$ cysteine residues. Numerous encoded small secreted proteins ( 205 in A. altimontana and 172 in A. solidipes) were annotated as CAZymes, peptidases, thaumatin, cerato-platanin, hydrophobins, etc. (Supplemental Files 3 and 4); however, for other predicted small secreted proteins (375 in A. altimontana and 353 in A. solidipes) the only annotation were BLASTp hits to "Uncharacterized 
protein", and there was no annotation for other predicted proteins (98 in A. altimontana and 69 in A. solidipes).

Non-secreted proteins. Numerous different functions were found among encoded proteins considered as non-secreted. Among them, those that matched CAZymes, cytochrome P450, transporters or secondary metabolite clusters were further examined (Table 3). Transporters and secondary metabolites clusters were also included in these analyses because they have also been considered important for the lifestyle of fungal species [86, 87]. The abundance of encoded proteins annotated as CAZymes, ABC transporters and secondary metabolite clusters were similar between $A$. altimontana and $A$. solidipes (Table 3 ); whereas numbers of cytochrome P450 and all transporters were larger in A. altimontana. However, the ratio $A$. altimontana / $A$. solidipes encoded protein numbers for most categories was smaller than the ratio of the genome sizes (1.32) and total proteins (1.18); only cytochrome P450 ratio was slightly higher (1.25) than the ratio of total proteins (Table 3).

Table 3

Total number of non-secreted proteins by gene family for Armillaria altimontana and $A$. solidipes. The genome sizes were included for comparison.

\begin{tabular}{|llll|}
\hline Feature & A. altimontana & A. solidipes & ratio \\
\hline Total non-secreted & 17,895 & 14,948 & 1.19 \\
\hline CAZymes-cytochrome P450 & $334-242$ & $305-195$ & $1.09-1.25$ \\
\hline Total transporters & 474 & 414 & 1.14 \\
\hline ABC transporters & 67 & 60 & 1.11 \\
\hline Secondary metabolite clusters & 21 & 19 & 1.10 \\
\hline Total proteins & 19,130 & 16,105 & 1.18 \\
\hline Genome size & $73,739,702$ & $55,735,298$ & 1.32 \\
\hline
\end{tabular}

When the abundance of the non-secreted CAZymes was grouped by substrate, the largest differences were found within encoded pectin-degrading enzymes with 58 in A. altimontana and 47 in A. solidipes, carbohydrate binding with 17 and 8 respectively; and lignin degrading enzymes with 49 and 41 respectively (Supplemental Figure 3). Overall, most non-secreted CAZymes numbers were typically higher in A. altimontana in comparison with A. solidipes.

Genes upregulated in rhizomorphs. We searched for genes reported by Sipos et al. [28] as notable genes that were upregulated in rhizomorphs. Most of the categories had similar numbers between both Armillaria species, although $A$. altimontana possessed 62 more genes encoding cytochrome P450 (Table 4). A diversity of functions has been ascribed to Cytochrome P450 proteins [88-91]. Caspase domaincontaining proteins, part of proteases that have been associated with programed cell death in other 
organisms [92], were more abundant (10 more) in A. solidipes. Relatively large differences were also found in numbers of genes encoding two enzymes involved in secondary metabolites synthesis:

polyprenyl synthase, involved in terpenoid synthesis $[93,94]$, had 23 in A. altimontana versus 12 in $A$. solidipes; while trichodiene synthase, which utilizes terpenoids to produce the trichodiene [94] was more abundant in $A$. solidipes with 12, versus only 3 in A. altimontana (Table 4). 
Table 4

Number of notable genes with overexpression in rhizomorphs (Sipos et al. 2017; 27) in the Armillaria altimontana and A. solidipes genome assemblies.

\begin{tabular}{|c|c|c|}
\hline protein coded (Pfam terms) & $\begin{array}{l}\text { A. } \\
\text { altimontana }\end{array}$ & $\begin{array}{l}\text { A. } \\
\text { solidipes }\end{array}$ \\
\hline expansin (PF03330) & 12 & 8 \\
\hline bzip transcription factor (PF00170) & 5 & 5 \\
\hline $\begin{array}{l}\text { zinc finger c2h2 (PF00096, PF12874, PF12756, PF06220, PF16278, } \\
\text { PF08790) }\end{array}$ & 62 & 68 \\
\hline caspase domain (PF00656, PF14538) & 30 & 40 \\
\hline hydrophobin (PF01185) & 7 & 4 \\
\hline cytochrome P450 (PF00067) & 271 & 209 \\
\hline GH28 (PF00295) & 17 & 16 \\
\hline pectinesterase (PF01095) & 9 & 10 \\
\hline GH88 (GH105) (PF07470) & 6 & 5 \\
\hline PL3 (PF03211) & 9 & 10 \\
\hline GH3 (PF00933) & 16 & 14 \\
\hline GH43 (PF04616) & 11 & 10 \\
\hline GH76 (PF03663) & 6 & 5 \\
\hline AA9 (PF03443) & 18 & 21 \\
\hline Total cellulases & 183 & 179 \\
\hline cellulase (PF00150) & 19 & 19 \\
\hline POD (PF00141; PF11895) & 10 & 11 \\
\hline HTP (PF01328) & 6 & 6 \\
\hline laccase (PF00394) & 25 & 28 \\
\hline cerato-platanin (PF07249) & 4 & 4 \\
\hline carboxylesterase (PF00135) & 32 & 37 \\
\hline family 6 bacterial extracellular solute-binding protein (PF13343) & 2 & 1 \\
\hline polyketide synthase (PF14765) & 10 & 7 \\
\hline trichodiene synthase (PF06330) & 3 & 12 \\
\hline polyprenyl synthase (PF00348) & 23 & 12 \\
\hline
\end{tabular}


Orthologous and non-orthologous proteins. Although approximately $62 \%$ of $A$. altimontana and $72 \%$ of $A$. solidipes proteins grouped in 10,989 clusters of orthologous proteins, a large number, 7,232, of proteins were non-orthologous in A. altimontana, and 4,575 were non-orthologous in A. solidipes (Figure 4).

Out of the 10,989 clusters of orthologous proteins, 10,321 were two protein clusters, made from one protein from each species; only 29 clusters had a difference larger than 5 proteins. Of those, 24 cluster had more $A$. altimontana proteins, whereas there were five clusters that $A$. solidipes had a greater number of proteins. Out of those 29 clusters, one of them contained CBM67 proteins, which bind rhamnose residues in pectin, with 15 proteins from $A$. altimontana versus only one from $A$. solidipes. Another cluster contained $\mathrm{ABC}$ transporters, of which, $A$. altimontana also had ten more than $A$. solidipes. Two clusters contained caspase-domain proteins, with 17 more from $A$. solidipes than from $A$. altimontana. Other clusters corresponded to transposases, transcription factors, helicases, F-box proteins, and histonemodifying enzymes, while no annotation was found for 14 clusters (Table 5). 
Table 5

Orthologus and non-orthologous proteins in Armillaria altimontana - Armillaria solidipes comparison.

Only information for proteins with count difference larger than 5 were included, except for non-

orthologous terpene synthase and transcriptional activator of glycolytic enzymes with 4 present only in A.

altimontana.

\section{Orthologous proteins}

\begin{tabular}{|c|c|c|c|c|}
\hline 2 protein clusters & 10,321 & & & \\
\hline 3-5 protein clusters & 576 & & & \\
\hline$>5$ protein cluster & 29 & & & \\
\hline cluster_name & $\begin{array}{l}\text { protein } \\
\text { number }\end{array}$ & annotation & $\begin{array}{l}\text { A. } \\
\text { altimontana }\end{array}$ & $\begin{array}{l}\text { A. } \\
\text { solidipes }\end{array}$ \\
\hline cluster1 & 30 & transposase & 28 & 2 \\
\hline cluster6 & 19 & $\begin{array}{l}\text { BTB/POZ domain protein, } \\
\text { maybe transcription factor }\end{array}$ & 18 & 1 \\
\hline cluster12 & 16 & $\begin{array}{l}\text { CBM67, rhamnose binding } \\
\text { in polysaccharides (pectin) }\end{array}$ & 15 & 1 \\
\hline cluster13 & 16 & $\begin{array}{l}\text { only one protein with: Zinc } \\
\text { kucle domain }\end{array}$ & 15 & 1 \\
\hline cluster2 & 21 & $\begin{array}{l}\text { helicase, involved in } \\
\text { telomere maintenance }\end{array}$ & 15 & 6 \\
\hline cluster4 & 21 & no annotation & 14 & 7 \\
\hline cluster19 & 14 & no annotation & 13 & 1 \\
\hline cluster14 & 15 & no annotation & 13 & 2 \\
\hline cluster27 & 13 & $\begin{array}{l}\text { F-box domain protein, } \\
\text { different functions } \\
\text { including fungal } \\
\text { pathogenesis }\end{array}$ & 12 & 1 \\
\hline cluster31 & 12 & no annotation & 11 & 1 \\
\hline cluster30 & 12 & $\mathrm{ABC}$ transporter & 11 & 1 \\
\hline cluster24 & 13 & no annotation & 11 & 2 \\
\hline cluster53 & 10 & no annotation & 9 & 1 \\
\hline cluster55 & 10 & $\begin{array}{l}\text { only one protein with: } \\
\text { uncharacterized domain }\end{array}$ & 9 & 1 \\
\hline cluster61 & 9 & no annotation & 8 & 1 \\
\hline cluster63 & 9 & transposase & 8 & 1 \\
\hline cluster68 & 9 & no annotation & 8 & 1 \\
\hline
\end{tabular}




\section{Orthologous proteins}

\begin{tabular}{|c|c|c|c|c|}
\hline cluster70 & 9 & no annotation & 8 & 1 \\
\hline cluster73 & 9 & no annotation & 8 & 1 \\
\hline cluster74 & 9 & no annotation & 8 & 1 \\
\hline cluster79 & 9 & $\begin{array}{l}\text { helicase, involved in } \\
\text { telomere maintenance }\end{array}$ & 8 & 1 \\
\hline cluster54 & 10 & no annotation & 8 & 2 \\
\hline cluster44 & 10 & $\begin{array}{l}\text { SET domain protein, } \\
\text { histone modifying enzymes }\end{array}$ & 8 & 2 \\
\hline cluster81 & 8 & no annotation & 7 & 1 \\
\hline cluster40 & 11 & $\begin{array}{l}\text { only three proteins with: } \\
\text { domain of unknown } \\
\text { function }\end{array}$ & 2 & 9 \\
\hline cluster10 & 19 & $\begin{array}{l}\text { F-box domain protein, } \\
\text { different functions } \\
\text { including fungal } \\
\text { pathogenesis }\end{array}$ & 2 & 17 \\
\hline cluster99 & 8 & caspase domain protein & 1 & 7 \\
\hline cluster100 & 8 & no annotation & 1 & 7 \\
\hline cluster28 & 13 & caspase domain protein & 1 & 12 \\
\hline \multicolumn{5}{|c|}{ Non-orthologous proteins } \\
\hline & $\begin{array}{l}\text { A. } \\
\text { altimontana }\end{array}$ & A. solidipes & & \\
\hline Cazymes & 91 & 80 & & \\
\hline Cytochrome P450 & 87 & 48 & & \\
\hline
\end{tabular}

Other proteins with count difference $>5$

\begin{tabular}{lll} 
polyprenyl synthase & 15 & 6 \\
\hline trichodiene synthase & 2 & 11 \\
\hline F-box protein & 81 & 52 \\
\hline glutathione S-transferase & 1 & 11 \\
$\begin{array}{l}\text { Clp amino terminal } \\
\text { domain, pathogenicity } \\
\text { island component }\end{array}$ & 6 & 0 \\
\hline
\end{tabular}




\section{Orthologous proteins}

\begin{tabular}{lll}
$\begin{array}{l}\text { DDE superfamily } \\
\text { endonuclease }\end{array}$ & 8 & 0 \\
$\begin{array}{l}\text { Sodium/hydrogen } \\
\text { exchanger family }\end{array}$ & 0 & 8 \\
$\begin{array}{l}\text { Secreted proteins/small } \\
\text { secreted proteins }\end{array}$ & $344 / 327$ & $265 / 248$ \\
\hline
\end{tabular}

Exclusive with possible host-interaction function

terpene synthase $\quad 4 \quad 0$

transcriptional activator of $4 \quad 0$ glycolytic enzymes

CAZymes and cytochrome P450 enzymes were found among non-orthologous proteins. The number of non-orthologous CAZymes was 91 in A. altimontana and 80 in A. solidipes, with small differences in number of individual CAZymes between the two species, which is similar to the differences found in secreted and in non-secreted CAZymes. A few non-orthologous CAZymes were exclusive, but only GT32 was found exclusively in $A$. altimontana among CAZymes with a count of greater than 5 . For cytochrome P450, the difference was larger: 39 more in A. altimontana (Table 5); slightly smaller than the difference, 46, of total cytochrome P450 proteins (244 in A. altimontana vs 198 in A. solidipes).

Many other proteins that were present in both A. altimontana and $A$. solidipes with the same PfamInterpro annotation were still considered non-orthologous by OrthoVenn2, and their numbers were also similar in most cases. Those with a number difference greater than 5 included polyprenyl synthase, trichodiene synthase, F-box protein, and glutathione S-transferase. Other proteins were present only in one Armillaria species, most of them occurred in small numbers: three with counts greater than 5: Clp amino terminal domain pathogenicity island component, and DDE superfamily endonuclease, only in $A$. altimontana; Sodium/hydrogen exchanger family, only in A. solidipes. Other non-orthologous proteins with smaller numbers, but with a possible host-pathogen interaction function, included terpene synthase (4) and transcriptional activator of glycolytic enzymes (4), which were found only in A. altimontana.

Finally, 344 A. altimontana non-orthologous proteins were predicted as secreted with 327 of them as small secreted proteins. For non-orthologous proteins from A. solidipes, 265 were predicted as secreted with 248 of them as small secreted protein (Table 5).

Armillaria species identified from field plots. Rhizomorphs were isolated from 51 total trees, yielding 87 rhizomorph samples that all produced pure Armillaria cultures. Sequencing the tef1 gene from the 87 rhizomorph samples resulted in 48 trees associated with $A$. altimontana, 3 trees associated with $A$. solidipes. Twelve trees resulted in unsuccessful rhizomorph isolation, therefore these samples were not 
utilized in analyses. Sequences corresponding to both A. altimontana and $A$. solidipes resulted in $99 \%$ identity during blast searches on the NCBI database.

Processing sequenced 16S and ITS2 libraries in Mothur. From the soil samples, a total of 2,156,476 and 4,323,028 raw paired-end $2 \times 250 \mathrm{bp}$ reads from 56 samples were generated from $16 \mathrm{~S}$ and ITS sequencing, respectively. For the $16 \mathrm{~S}$ dataset, the mean sequencing depth after processing was 27,639 reads/sample, with a range from 6 to 107,582. Eighteen samples yielded $<5,000$ total reads and were removed from analyses for the $16 \mathrm{~S}$ dataset. For the ITS dataset, the mean sequencing depth after processing was 51,806 reads/sample, with a range from 15,017 to 77,969 . The total datasets yielded 26,781 and 6,936 OTUs for the $16 \mathrm{~S}$ and ITS2, respectively. The resulting rarefaction curves for these $16 \mathrm{~S}$ sequence data indicating adequate sampling depth (Supplementary Figure 4). Matching to the Silva database resulted in a16S dataset of 6,677 unique OTUs and matching to the UNITE database resulted in an ITS2 dataset of 2,806 unique OTUs.

Analyses of microbial communities. Samples were grouped into treatments associated with species of Armillaria (A. altimontana or A. solidipes). Non-metric, multidimensional scaling (NMDS) plots indicated that soil bacterial communities differed more than the fungal communities associated with both $A$. altimontana and $A$. solidipes (Supplemental Figure 4).

Differences in community alpha diversity and richness. Bacterial and fungal communities were assessed for overall rarefied richness and diversity. We did not observe significant differences in richness among soil fungal communities associated with $A$. solidipes or $A$. altimontana $\left(\mathrm{F}_{(1,52)}=0.0462, P=0.8310\right)$. Additionally, we did not observe significant fungal differences for either diversity index (Shannon's or Inverse Simpson) associated with $A$. solidipes or $A$. altimontana $\left(\mathrm{F}_{(1,52)}=0.16, P=0.6910 ; \mathrm{F}_{(1,52)}=\right.$ $0.5729, P=0.4530$ ). Although not statistically significant, soils associated with $A$. solidipes had greater fungal richness and diversity, compared to $A$. altimontana. Bacterial richness measurements indicated that soils associated Armillaria species were slightly significant $\left(\mathrm{F}_{(1,34)}=3.905, P=0.0563\right)$ with $A$. altimontana having greater richness. For both diversity indices, soils associated with $A$. altimontana had greater bacterial community diversity. Shannon's diversity was slightly significant $\left(\mathrm{F}_{(1,34)}=4.0619, P=\right.$ 0.0518), though the Inverse Simpson index was not significant between Armillaria species $\left(\mathrm{F}_{(1,34)}=\right.$ $1.4005, P=0.2448)$.

Additionally, $A$. altimontana, has a slightly significant positive relationship with fungal richness $(P=$ 0.053; Supplemental Table 2). To analyze diversity measurements, the Shannon's diversity model was not significant $(P=0.489)$, while $A$. altimontana $(P=0.067$; positive) and soil moisture $(P=0.078$; negative $)$ both had an influence on diversity. The ANOVA model for Inverse Simpsons was not significant $(P=$ 0.558), as no variables were significant to the Inverse Simpson for fungal communities (Supplemental Table 2). Soil moisture had a significant negative relationship with bacterial richness $(P=0.013$; Supplemental Table 3$)$. Both $A$. solidipes $(P=0.039)$ and soil moisture $(P=0.022)$ had a significant negative relationship with bacterial Shannon's diversity. The bacterial Inverse Simpson diversity model 
was significant $(P=0.0423)$, with soil moisture $(P=0.024$, negative $)$ as the lone significant predictor (Supplemental Table 3).

Bacterial and fungal beta diversity. Principal components analysis ( $\mathrm{PCOA}$ ) was completed to quantify beta diversity between bacterial and fungal communities associated with each Armillaria species. Beta diversity associated with soil bacterial communities of $A$. altimontana and $A$. solidipes were not significantly different $(P=0.544)$, and this is observed in the PCoA plot (Supplemental Figure 5). We also observed that beta diversity indices were significantly different for fungal soil communities associated with Armillaria species as well $(P=0.016)$ (Supplemental Figure 5).

Core communities associated with Armillaria species. Venn diagrams were constructed to identify the individual and core bacterial and fungal communities. Of the 6,677 total OTUs, the core bacterial communities for soils associated with both Armillaria species consisted of 955 OTUs (14.3\%). While a significant abundance, 5,643 OTUs (84.5\%), were uniquely associated with A. altimontana, only 79 (1.2\%) were uniquely associated with $A$. solidipes (Figure $4 \mathrm{~b}$ ). The core fungal community associated with both A. altimontana and $A$. solidipes consisted of 521 OTUs (18.6\%). Far surpassing the core community, 2,219 OTUs (79.1\%) were unique to $A$. altimontana-associated soils, whereas only $66(2.4 \%)$ OTUs were unique to $A$. solidipes-associated soils (Figure $4 \mathrm{c}$ ).

Taxonomic trends and relative abundance. There were $1716 \mathrm{~S}$ bacterial families that exceeded the relative abundance of $1 \%$ (Figure $5 \mathrm{~A}$ ). All 17 families were in soils associated with $\mathrm{A}$. altimontana. Pseudomonadadaceae was found in high abundance followed by Chthoniobacetaceae and Pyrinomonadaeae. Within the two soil bacterial communities associated with $A$. solidipes, we observed a large relative abundance of Entobacteriaceae, followed by Pseudomonadaceae (Figure 5A).

In total, 17 fungal families exceeded a relative abundance of 1\% (Figure 5B). Mortierellaecea, Inocybaceae, Atheliaceae, Hypocreales, and Leotiomycetes were found in high relative abundance in soils associated with $A$. altimontana. Qualitatively, similar fungal families were observed in the three soil samples associated with $A$. solidipes, including Mortierellaceae, Leotiomycete, Inocybaceae, and Hypocreaceae, although at higher relatively abundance compared to A. altimontana (Figure 5B).

MetagenomeSeq analysis. We identified a total of four bacterial taxa that contributed significantly to the differential comparison between Armillaria species using the magnitude of OTU log-fold change (Figure 6 A). A proliferation, at $90 \%$ confidence, of Nitrosococcaceae (wb1-P19), Solirubrobacteraceae, Enterobacteriaceae, and Gammoproteobacteria_PLTA13_fa were found in A. solidipes-associated soils; whereas, only uncultured bacteria were found to be significantly greater in A. altimontana-associated soils. We identified a total of five fungal taxa that contributed significantly to the comparison between Armillaria species using the magnitude of OTU log-fold change at the $90 \%$ confidence level (Figure 6B). These analyses identified a proliferation of Atheliaceae, Sulliaceae, Rhizopogonaeae, and unclassified 
fungi in A. altimontana-associated soils; whereas only a single OTU (unclassified fungi) was significantly more abundant in $A$. solidipes-associated soils.

\section{Discussion}

We report the high-quality genome assemblies of two Armillaria species (A. altimontana and $A$. solidipes) that display different ecological behaviors, with structural and functional annotations. In addition, we examined the potential role and relationship among microbial communities that may correspond with the different ecological roles of $A$. altimontana and $A$. solidipes. Armillaria isolates were obtained from a conifer forest in northern Idaho within the interior western USA, where A. altimontana primarily behaves as a saprophyte and potentially beneficial biocontrol agent enhancing the growth/survival of western white pine [20] and $A$. solidipes primarily acts as an aggressive pathogen of diverse conifers $[11,13,95]$. In a whole-genome phylogenomic tree, $A$. cepistipes and $A$. gallica, which are often considered as weak or opportunistic pathogens, are closely related to $A$. altimontana. This result is similar to other published phylogenetic trees, where $A$. altimontana tends to group with less virulent pathogens (e.g., A. cepistipes, $A$. calvescens, $A$. gallica, and $A$. nabsnona) within the Gallica superclade, which is well separated from the $A$. solidipes group (e.g. A. ostoyae, A. gemina, and A. sinapina) within the Solidipes/Ostoyae superclade $[22,23 ; 96]$. The phylogenetic placement of $A$. altimontana, compared to $A$. mellea, virulent pathogen within Mellea superclade, which is ancestral to the Gallica superclade, suggests that perhaps $A$. altimontana is evolving towards lower virulence.

The genome assemblies presented here were similar in size to other Armillaria genomes assemblies, although our $A$. solidipes genome is smaller than the A. solidipes/ostoyae 28-4 genome of Anderson and Spatafora (58.01 Mbp; JGI web site); this could be attributable to the different sequencing technologies used (PacBio and Illumina, respectively), and/or different isolates sequenced. Both $A$. solidipes assemblies are, however, smaller than the $A$. ostoyae C18/9 (60.1 Mbp) assembly from Europe [28]. Although it has been proposed that $A$. solidipes and $A$. ostoyae are a single species [97], genomic differences result in a separate grouping for $A$. ostoyae (C18/9) from Europe, which is distinct from the two $A$. solidipes isolates from North America in the whole genome phylogenetic tree. Thus, the phylogenomic analysis further supports that North American A. solidipes is distinct from Eurasian $A$. ostoyae.

Armillaria altimontana has a larger genome and a proportionately larger number of protein-coding genes compared to $A$. solidipes. It had twice as many sequences coding for repetitive elements $(18,346,415 \mathrm{bp})$ than A. solidipes $(9,691,790 \mathrm{bp})$; however, this difference is less than would be accounted for from the larger genome size alone (73.7 Mbp versus $55.7 \mathrm{Mbp}$, respectively). Rather, it has been suggested that gene family expansion has driven the increase of genome sizes in Armillaria in comparison with other Agaricales [28], and this could also be the mechanism responsible for the expanded genomes of $A$. altimontana, $A$. cepistipes (75.5 Mbp), and $A$. gallica (85.3 Mbp). Nevertheless, the genomes of $A$. 
altimontana and $A$. solidipes shared large blocks of synteny (i.e., large blocks of gene order when comparing the two genomes) suggesting that their gene sets are similar within the genomes of two Armillaria species. Interestingly, A. altimontana genome encodes only slightly more secreted proteins, secreted CAZymes, ABC transporters, and secondary metabolite clusters, but with slightly fewer tRNA genes compared to $A$. solidipes; and it contains considerably more predicted non-secreted proteins.

Although relatively few genomic differences were observed, genome signatures of lifestyle differences between $A$. solidipes and $A$. altimontana were highlighted by the variation in putative secreted proteins. Approximately 1,200 encoded proteins in the two Armillaria genomes were found as potentially secreted, which could be potentially also considered as potential "effectors"- important proteins for interactions with a host [98]. Both species were well-equipped with genes encoding enzymes to degrade cell wall components, including cellulose, hemicellulose, lignin, pectin, proteins, and others. The major differences between the two Armillaria species are that $A$. altimontana had more carbohydrate-binding enzymes, beta-glucan- degrading enzymes, and more proteins with predicted to be involvement in host interactions (hydrophobin, cerato-platanin), especially small secreted proteins [99]. In contrast, the genome of $A$. solidipes, encoded more secreted putative cellulose, hemicellulose, pectin, and lignin-degrading enzymes. The combination of these secreted proteins could confer $A$. solidipes with a higher ability to infect and cause damage to its host. However, this hypothesis requires functional tests, because the number of CAZymes varies widely when comparing fungi with similar or different lifestyles [100]. Also, it has been found that phylogenetic history can have a more important influence on secretome composition than lifestyle [101].

We found that more than half of predicted proteins in $A$. altimontana and almost two thirds of $A$. solidipes predicted proteins could be considered orthologous. Most of these clusters had very similar numbers of proteins that were encoded in the genome of each Armillaria species. In contrast, all $A$. altimontana CBM67 proteins (15) were in a cluster, with only one CBM67 protein encoded by $A$. solidipes. Of the $15 \mathrm{~A}$. altimontana CBM67 proteins, 11 were predicted as secreted, as was the one $A$. solidipes CBM67 protein. CBM67 is one of several CBM considered "lectin-like" and we speculate that in Armillaria spp. CBM67 proteins may have an additional functionality other that help in pectin degradation, such as interactions with the host and other organisms [102], particularly in A. altimontana which contains more CBM67 genes.

Among non-orthologous proteins, another major difference was observed in the total numbers of gene encoding cytochrome P450 enzymes: A. altimontana had considerably more both non-orthologous cytochrome P450 genes and a higher total of all cytochrome P450 genes, which are known to be involved in numerous metabolic pathways and biological processes including degradation of lignin and xenobiotics, secondary metabolite synthesis, and adaptation to different environments [88-91]. The versatile activities of cytochrome P450 enzymes makes it difficult to assign a specific function for them, but we speculate that a larger number of genes encoding these enzymes, including many nonorthologous enzymes, could be associated with different lifestyles, in this case more saprophytic/mycorrhizal lifestyle for $A$. altimontana and a more pathogenic lifestyle for $A$. solidipes. A 
recent report also found a larger number of genes coding for cytochrome P450 in the saprophytic $A$. cepistipes compared to the pathogenic A. ostoyae[103].

Although non-orthologous proteins could have the similar molecular functions, their sequence differences could change their interactions with their substrates, or their regulation, or their environmental optima [104]. Furthermore, the expression levels and the timing of expression could account for important ecological differences in how the two Armillaria species interact with their hosts [103]. Variations in the expression of many genes, including some related to pathogenicity, have been observed even among strains of the same species, and these variations are associated with different levels of virulence during host infection [105].

Rhizomorphs are an important and unique means by which that Armillaria species interact with their environment, hosts, and substrates. Differences in microbial communities associated with each Armillaria species can perhaps be putatively attributed to genes encoding enzymes similar to those secondary metabolite synthesis enzymes previously identified in Armillaria species [28]. We observed some differences when comparing the number of genes upregulated in rhizomorphs in the two Armillaria species. For example, polyprenyl synthase genes involved in terpenoid synthesis were more abundant in A. altimontana compared to $A$. solidipes, whereas genes involved in the production of trichodiene, a potential signaling molecule or mycotoxin [106], were more abundant in A. solidipes. In general, terpenoids can have many different structures and functions, which have been involved in the interaction between fungi and plants and other organisms [107-110]. Trichodiene, on the other hand, is the immediate precursor to a family of toxins that cause damage to plant hosts [111].

Although overall differences of soil microbial communities were not observed in association with the two Armillaria species, several bacterial taxa were more abundant in soils associated with $A$. solidipes, and several fungal taxa were more abundant in association with $A$. altimontana. We identified the most significant logfold change of three Proteobacteria taxa within the Gammaproteobacteria class and Enterobacteriaceae in association with $A$. solidipes. Interestingly, one of these included Nitrosococcaceae wb1-P19, which is thought to be a nitrite-oxidizing autotrophic bacteria and that has previously been observed in caves [112-114]. In contrast, Gammaproteobacteria PLTA13_fa was found in high numbers in a Mn oxide-producing biofilm [115]. With these unique characteristics, it is not unexpected that some taxa within Proteobacteria have been characterized in soils contaminated with pesticides [116]. A recent study examining healthy ginseng and ginseng with rusty root also found that several Proteobacteria were found in high abundances among diseased plants [117], and increases in Proteobacteria were also observed in association with changes of cover types from forest to grasslands in Hawai'i [118]. In addition, Enterobacteriaceae taxa have been associated with higher levels of disease in Fusarium wilt disease of banana [119] but these taxa was found in higher levels in asymptomatic Kauri trees compared to those infected with Phytophthora agathidicide [120]. Similar to our study, however, Byers et al. [120] found that Solirubrobacterales were more abundant with trees in decline. Przemieniecki et al. [121] surveyed bacterial communities associated $A$. ostoyae rhizomorphs during three stages of tree decline. They observed that rhizomorphs that were rich in Parabacteriodes, Clostridium, and Bacillus were able to 
hydrolyze diverse organic compounds that could assist Armillaria rhizomorph enzymes in wood decomposition. Though these taxa were not present in our study, the high abundance of several taxa in the Proteobacteria and Enterobacteriaceae may suggest recruitment of bacterial taxa by $A$. solidipes to assist in wood degradation. Alternatively, these results could suggest that the abundance of these taxa may be associated with tree mortality and/or changes in the plant community due to the activity of $A$. solidipes. Further, as the rhizosphere of the infected tree begins to degrade, these taxa may thrive because of their unique abilities to breakdown complex plant root materials. Several studies have observed changes in bacterial communities associated with declines in plant communities [122-124]. More research is needed better understand signaling among members of the pathobiome during tree decline drives changes in the associated bacterial communities

We identified several fungal taxa that were more abundant in association with A. altimontana. Several of these taxa have been shown to increase plant productivity through multiple functions, such as ectomycorrhizal fungi including Atheliaceae, Rhizopogonaceae, and Suillaceae [125-128]. Taxa from all three ectomycorrhizal fungal families were significantly more abundant in soils associated with $A$. altimontana compared to $A$. solidipes, and these taxa are perhaps ectomycorrhizal, allowing increased uptake of water and nutrients to enhance tree defenses against root diseases [31]. The functions of these A. altimontana-associated, soil fungi suggest that these fungal communities may also contribute to the overall health of the forest stand, corroborating Warwell et al. [20], who found that trees associated with A. altimontana were larger in both diameter and height than trees not associated with this Armillaria species. It remains unknown if $A$. altimontana is conducive to mycorrhizal fungi though evidence provided herein suggests that $A$. altimontana co-occurs with mycorrhizal fungi.

Utilizing the natural soil fungal communities to assist in the management of Armillaria root disease may be key to long-term protection of residual trees on sites infested with pathogenic Armillaria spp., such as following Armillaria root disease-associated mortality or silvicultural thinning practices. Beneficial microbes can minimize pathogen inoculum loads by reducing pathogen growth or inhibiting pathogen infection of susceptible hosts [41]. In this study, a greater diversity of mycorrhizal and saprophytic fungi was observed in association with the beneficial/non-pathogenic $A$. altimontana, demonstrating that mycorrhizae may have a direct influence on hosts within forested environments associated with Armillaria species [125].

Selecting trees to sample Armillaria species was the greatest limiting factor in this study. More than 25 years before this study, $A$. solidipes was well represented on the site [20]. The small number of $A$. solidipes-infected trees in this study perhaps reflects the protective role of $A$. altimontana and the associated microbial community in suppressing $A$. solidipes; however, additional studies and surveys are needed to support this hypothesis. The survey approaches used in our study yielded rhizomorphs for $78 \%$ of the trees and adequate DNA from $90 \%$ of the samples. Additionally, the use of metatranscriptomics could further our understanding of the fungal microbes and their ecological functions within the soils associated with $A$. altimontana and $A$. solidipes. 
In conclusion, we found high similarity comparing the genomes of between the beneficial/nonpathogenic $A$. altimontana and pathogenic $A$. solidipes. The larger number of proteins encoded within $A$. altimontana genome results from moderate increases across many different gene families instead of a large expansion of a few gene families. However, we found many relatively small differences in genes that could contribute to differences in ecological lifestyles and interactions with woody hosts and soil microbes (fungi and bacteria). We did observe, however, that soil microbial communities may act in concert with $A$. altimontana to produce suppressive soils that help protect trees from Armillaria root disease, caused by $A$. solidipes. This study further suggests that novel approaches for managing Armillaria root disease could be based on management practices that favor naturally occurring, nonpathogenic Armillaria spp. and other beneficial soil microbes that suppress Armillaria root disease. Additionally, continued observations of microbial communities in association Armillaria spp. will provide additional insights on microbial changes over time in relation with Armillaria root disease and changing forest environments.

\section{Declarations}

\section{Acknowledgments}

We thank the USDA Forest Service, State \& Private forestry, Forest Health Protection, Special Technology Development Program and Joint Venture Agreements (19-JV-11221633-093 and 20-JV-11221633-141) to Colorado State University (JES) for partial funding of this study.

Author contributions: All authors contributed to the study conception and design. Material preparation and data collection were performed by Bradley Lalande, John Hanna, Mee-Sook Kim, Ned Klopfenstein and Jane Stewart. Analyses were performed by Jorge Ibarra Caballero, Bradley Lalande, and Jane Stewart. The first draft of the manuscript was written by Jorge Ibarra Caballero, Bradley Lalande and Jane Stewart, and all authors commented on previous versions of the manuscript. All authors read and approved the final manuscript.

Conflict of Interest: The authors declare that they have no conflict of interest.

Compliance with ethical standards: For this type of study formal consent is not required.

Funding: This study was funded in part by the USDA Forest Service, State \& Private forestry, Forest Health Protection, Special Technology Development Program and Joint Venture Agreements (19-JV-11221633093 and 20-JV-11221633-141) to Colorado State University (JES).

Data availability: The datasets generated during and/or analysed during the current study are available in the NCBI database. The corresponding genome assemblies were deposited at the NCBI with accession number JAIWYR000000000 for A. altimontana, and JAIWYQ000000000 for A. solidipes, and microbial dataset is in NCBI SRA database under accession number PRJNA767898. 


\section{References}

1. Hess J, Skrede I, Chaib De Mares M, Hainaut M, Henrissat B, Pringle A (2018) Rapid divergence of genome architectures following the origin of an ectomycorrhizal symbiosis in the gene Amanita. Molecular Biology and Evolution. 35:2786-2804. doi.org/10.1093/molbev/msy179.

2. Möller M, Stukenbrock EH (2017) Evolution and genome architecture in fungal plant pathogens. Nature Reviews Microbiology. 15:756-771. DOI: 10.1038/nrmicro.2017.76.

3. Ryberg M, Matheny PB (2012) Asynchronous origins of ectomycorrhial clades of Agaricales. Proceedings of the Royal Society B. 279:2003-2011. doi.org/10.1098/rspb.2011.2428.

4. Tedersoo L, May TW, Smith ME (2010). Ectomycorrhizal lifestyle in fungi: global diversity, distribution, and evolution of phylogenetic lineages. Mycorrhiza. 20:217-263. doi: 10.1007/s00572009-0274-x.

5. Kohler A, Kuo A, Nagy L. et al. (2015) Convergent losses of decay mechanisms and rapid turnover of symbiosis genes in mycorrhizal mutualists. Nature Genetics. 47:410-415. doi.org/10.1038/ng.3223.

6. Veneault-Fourrey C, Commun C, Kohler A, Morin E, Balestrini R, Plett J, Danchin E, Coutinho P, Wiebenga A, DeVries RP, Henrissat B, Martin F (2014) Genomic and transcriptomic analysis of Laccaria bicolor CAZome reveals insights into polysaccharides remodelling during symbiosis establishment. Fungal Genetics and Biology. 72:168-181. doi: 10.1016/j.fgb.2014.08.007.

7. Dalman K, Himmelstrand K, Olson A, Lind M, Brandstörm-During M, Stenlid J (2013) A genome-wide association study identifies genomic regions for virulence in the non-model organism Heterobasidion annosum s.s. PLoSOne. 8:e53525. doi: 10.1371/journal.pone.0053525.

8. Zeng Z, Sun H, Vainio EJ, Raffaello T, Kovalchuk A, Morin E, Duplessis S, Asiegbu FO (2018) Intraspecific comparative genomics of isolates of the Norway spruce pathogen (Heterobaidion parviporum) and identification of its potential virulence factors. BMC Genomics. 19:220. doi.org/10.1186/s12864-018-4610-4.

9. Castanera R, Borgognone A, Pisbarro AG, Ramírez L (2017) Biology, dynamics and applications of transposable elements in basidiomycete fungi. Applied Microbiology and Biotechnology. 101: 13371350. DOI 10.1007/s00253-017-8097-8.

10. Marçais B, Bréda N (2006) Role of an opportunistic pathogen in the decline of stressed oak trees. Journal of Ecology. 94:1214-1223. doi.org/10.1111/j.1365-2745.2006.01173.x.

11. Baumgartner K, Coetzee MPA, Hoffmeister D (2011) Secrets of the subterranean pathosystem of Armillaria. Molecular Plant Pathology. 12:515-534. doi.org/10.1111/j.1364-3703.2010.00693.x.

12. Cleary MR, van der Kamp BJ, Morrison DJ (2012) Pathogenicity and virulence of Armillaria sinapina and host response to infection in Douglas-fir, western hemlock and western redcedar in the southern Interior of British Columbia. Forest Pathology. 42:481-491. https://doi.org/10.1111/j.14390329.2012.00782.x.

13. Heinzelmann R, Prospero S, Rigling D (2017) Virulence and Stump Colonization Ability of Armillaria borealis on Norway Spruce Seedlings in Comparison to Sympatric Armillaria species. Plant Disease. 
101:470-479. doi.org/10.1094/PDIS-06-16-0933-RE.

14. Morrison DJ, Pellow KW (2002) Variation in virulence among isolates of Armillaria ostoyae. Forest Pathology. 32:99-107. DOI: 10.1046/j.1439-0329.2002.00275.x.

15. Morrison DJ (2004) Rhizomorph growth habit, saprophytic ability and virulence of 15 Armillaria species. Forest Pathology 34:15-26. DOI: 10.1046/j.1439-0329.2003.00345.x.

16. Prospero S, Holdenrieder O, Rigling D (2004) Comparison of the virulence of Armillaria cepistipes and Armillaria ostoyae on four Norway spruce provenances. Forest Pathology. 34:1-14. doi.org/10.1046/j.1437-4781.2003.00339.x.

17. Brazee NJ, Ortiz-Santana B, Banik MT, Lindner DL (2012) Armillaria altimontana, a new species from the western interior of North America. Mycologia. 104(5):1200-1205. DOI: 10.3852/11-409.

18. Ferguson BA, Dreisbach TA, Parks CG, Filip G, Schmitt CL (2003) Coarse-scale population structure of pathogenic Armillaria species in a mixed conifer forest in the Blue Mountains of northeast Oregon. Canadian Journal of Forest Research. 33:612-633. DOI: 10.1139/x03-065.

19. Kim M-S, Klopfenstein NB, McDonald GI, Arumuganathan K, Vidaver AK (2000) Characterization of North America Armillaria Species by Nuclear DNA Content and RFLP Analysis. Mycologia. 92:874883. doi.org/10.1080/00275514.2000.12061232.

20. Warwell MV, McDonald GI, Hanna JW, Kim MS, Lalande BM, Stewart JE, Hudak AT, Klopfenstein NB (2019) Armillaria altimontana is associated with healthy western white pine (Pinus monticola): Potential in situ biological control of Armillaria root disease pathogen, A. solidipes. Forests.10:294. DOI: https://doi.org/10.3390/f10040294.

21. Rizzo DM, Harrington TC (1993) Delineation and biology of clones of Armillaria ostoyae, A. gemina and $A$. calvescens. Mycologia, 85(2):164-174. doi.org/10.2307/3760452.

22. Klopfenstein NB, Stewart JE, Ota Y, Hanna JW, Richardson BA, Ross-Davis AL, Elías-Román RD, Korhonen K, Keča N, Iturritxa E, Alvarado-Rosales D, Solheim H, Brazee NJ, Łakomy P, Cleary MR, Hasegawa E, Kikuchi T, Garza-Ocañas F, Tsopelas P, Rigling D, Prospero S, Tsykun T, Bérubé JA, Stefani FOP, Jafarpour S, Antonín V, Tomšovský M, McDonald GI, Woodward S, Kim MS (2017) Insights into the phylogeny of Northern Hemisphere Armillaria: Neighbor-net and Bayesian analyses of translation elongation factor 1-a gene sequences. Mycologia. 109:75-91. doi.org/10.1080/00275514.2017.1286572.

23. Koch RA, Wilson AW, Séné O, Henkel TW, Aime MC (2017) Resolved phylogeny and biogeography of the root pathogen Armillaria and its gasteroid relative, Guyanagaster. BMC Evolutionary Biology. 17:33-48. doi.org/10.1186/s12862-017-0877-3.

24. Heinzelmann R, Dutech C, Tsykun T, Labbé F, Soularue J-P, Prospero S (2019) Latest advances and future perspectives in Armillaria research. Canadian Journal of Plant Pathology. 41:1-23. doi.org/10.1080/07060661.2018.1558284.

25. Devkota P, Hammerschmidt R (2020) The infection process of Armillaria mellea and Armillaria solidipes. Physiological and Molecular Plant Pathology. 112:101543.

DOI:10.1016/j.pmpp.2020.101543. 
26. Collins C, Keane TM, Turner DJ, O'Keefe G, Fitzpatrick DA, Doyle, S (2013) Genomic and Proteomic Dissection of the Ubiquitous Plant Pathogen, Armillaria mellea: Toward a New Infection Model System. Journal of Proteome Research. 12:2552-2570. doi: 10.1021/pr301131t.

27. Ross-Davis AL, Stewart JE, Hanna JW, Kim M-S, Cronn R, Rai H, Richardson BR, McDonald GI, Klopfenstein NB (2013)Transcriptome characterization of an Armillaria root disease pathogen reveals candidate pathogenicity-related genes.Forest Pathology. 43:468-477. DOI: 10.1111/efp.12056.

28. Sipos G, Prasanna AN, Walter MC, O’Connor E, Bálint B, Krizsán K, Kiss B, Hess J, Varga T, Slot J, Riley R, Bóka B, Rigling D, Barry K, Lee J, Mihaltcheva S, LaButti K, Lipzen A, Waldron R, Moloney NM, Sperisen C, Kredics L, Vágvölgyi C, Patrignani A, Fitzpatrick D, Nagy I, Doyle S, Anderson JB, Grigoriev IV, Güldener U, Münsterkötter M, Nagy LG (2017) Genome expansion and lineage-specific genetic innovations in the forest pathogenic fungi Armillaria. Nature Ecology and Evolution 1:1931-1941. doi.org/10.1038/s41559-017-0347-8.

29. Azul AM, Nunes J, Ferreira I, Coehlo AS, Verissmo P, Trovao J, Campos A, Castro O, Freitas H (2014) Valuing native ectomycorrhizal fungi as a Mediterranean forestry component for sustainable and innovative solutions. Botany. 92:161-171. dx.doi.org/10.1139/cjb-2013-0170.

30. Baldrian P (2017) Forest microbiome: Diversity, complexity, and dynamics. FEMSMicrobiology. 42:109-130. doi.org/10.1093/femsre/fuw040.

31. Leake J, Johnson D, Donnelly D, Muckle G, Boddy L, Read D (2004) Networks of power and influence: The role of mycorrhizal mycelium in controlling plant communities and agroecosystem functioning. Canadian Journal of Botany. 82:1016-1045. doi.org/10.1139/b04-060.

32. Lee Taylor D, Sinsabaugh RL (2014) Chapter 4: The soil fungi: Occurrence, phylogeny, and ecology. In E.A. Paul (4th ed.), Soil microbiology, ecology and biochemistry. Cambridge, MA: Academic Press. p. 339-382. eBook ISBN: 9780123914118. https://doi.org/10.1016/C2011-0-05497-2.

33. Saif SR, Khan AG (1975) The influence of season and stage of development of plant on endogone mycorrhiza of field-grown wheat. Canadian Journal of Microbiology. 82:1020-1024. DOI: 10.1139/m75-151.

34. Cardenas E, Kranabetter JM, Hope G, Maas KR, Hallam S, Mohn WM (2015) Forest harvesting reduces the soil metagenomic potential for biomass decomposition. ISME. 9: 2465-2476. DOI: 10.1038/ismej.2015.57.

35. Chapman SK, Koch GW (2007) What type of diversity yields synergy during mixed litter decomposition in a natural forest ecosystem? Plant Soil. 299: 153-162. 10.1007/s11104-007-9372-8.

36. Davidson EA, Janssens IA (2006) Temperature sensitivity of soil carbon decomposition and feedbacks to climate change. Nature. 440:165-173. doi.org/10.1038/nature04514.

37. Robertson GP, Groffman PM (2014) Chapter 14: Nitrogen transformation. In E.A. Paul (4th ed.), Soil microbiology, ecology and biochemistry. Cambridge, MA: Academic Press. p. 339-382. eBook ISBN: 9780123914118. https://doi.org/10.1016/C2011-0-05497-2. 
38. Schloter M, Dilly O, Munch JC (2003) Indicators for evaluating soil quality. Agriculture, Ecosystems, and Environment. 98:255-262. doi.org/10.1016/S0167-8809(03)00085-9.

39. Allison SD, Martiny JBH (2008) Resistance, resilience, and redundancy in microbial communities. PNAS. 105(1):11512-11519. doi.org/10.1073/pnas.0801925105.

40. Horwath W (2014) Chapter 12: Carbon cycling: The dynamics and formation of organic matter. In E.A. Paul (4th ed.), Soil microbiology, ecology and biochemistry. Cambridge, MA: Academic Press. p. 339-382. eBook ISBN: 9780123914118. https://doi.org/10.1016/C2011-0-05497-2.

41. Kile GA, McDonald GI, Byler JW (1991) Ecology and disease in natural forests. In: C.G. Shaw and G.A. Kile, Armillaria Root Disease. United States Department of Agriculture Forest Service. Agricultural Handbook No. 691. Washington D.C. p. 102-121.

42. Kim MS, Ross-Davis AL, Stewart JE, Hanna JW, Warwell MV, Zambino PJ, Cleaver C, McDonald GI, Page-Dumroese DS, Moltzan B, Klopfenstein NB (2016) Can metagenomic studies of soil microbial communities provide novel insights toward developing novel management approaches for Armillaria root disease? Ramsey, A. and Palacios, P., compilers. Proceedings of the 63rd annual Western International Forest Disease Work Conference, Sept. 21-25, 2015. Newport, OR, USA.

43. Stewart JE, Kim M-S, Lalande, BM, Klopfenstein NB (2021) Pathobiome and microbial communities associated with forest tree root diseases [Chapter 15]. In: Asiegbu, Fred O.; Kovalchuk, Andriy, eds. Forest Microbiology - Tree Microbiome: Phyllosphere, Endosphere, and Rhizosphere, Volume 1. London, UK: Academic Press, Elsevier, Inc. p. 277-292. https://doi.org/10.1016/C2019-0-03562-5.

44. Kedves $O$, Shahab D, Champramary S, Chen L, Indic G, Bóka B, Nagy VD, Vágvölgyi C, Kredics L, Sipos G (2021) Epidemiology, biotic interactions, and biological control of Armillarioids in the Northern Hemisphere. Pathogens. 10:76. doi.org/10.3390/pathogens10010076.

45. Ross-Davis A, Settles M, Hanna JW, Shaw JD, Hudak AT, Page-Dumroese DS, Klopfenstein NB (2015) Using a metagenomic approach to improve our understanding of Armillaria root disease. pp. 73-78 in: Murray, M. and Palacios, P., compilers. Proceedings of the 62 nd annual Western International Forest Disease Work Conference, Sept. 8-12, 2014. Cedar City, UT, USA.

46. Gurevich A, Saveliev V, Vyahhi N, Tesler G (2013) QUAST: quality assessment tool for genome assemblies. Bioinformatics. 29(8):1072-1075. doi: 10.1093/bioinformatics/btt086.

47. Simão FA, Waterhouse RM, loannidis P, Kriventseva EV, Zdobnov EM (2015) BUSCO: assessing genome assembly and annotation completeness with single-copy orthologs. Bioinformatics 31(19):3210-3212. doi.org/10.1093/bioinformatics/btv351.

48. Bertels F, Silander OK, Pachkov M, Rainey PB, van Nimwegen E (2014) Automated reconstruction of whole genome phylogenies from short sequence reads. Molecular Biology and Evolution. 31(5):10771088. DOI: $10.1093 / \mathrm{molbev} / \mathrm{msu} 088$.

49. Langmead, B. and Salzberg, S.L. 2012. Fast gapped-read alignment with Bowtie 2. Nature Methods 9:357-359. doi: 10.1038/nmeth.1923.

50. Guindon S, Dufayard JF, Lefort V, Anisimova M, Hordijk W, Gascuel O (2010) New Algorithms and Methods to Estimate Maximum-Likelihood Phylogenies: Assessing the Performance of PhyML 3.0. 
Systematic Biology. 59(3):307-21. doi.org/10.1093/sysbio/syq010.

51. Smit AFA, Hubley R (2015) RepeatModeler Open-1.0. 2013-2015. Available from: www. repeatmasker.org.

52. Cantarel BL, Korf I, Robb SMC, Parra G, Ross E, Moore B, Holt C, Sánchez Alvarado A, Yandell M (2008) MAKER: An easy-to-use annotation pipeline designed for emerging model organism genomes. Genome Research 18(1):188-196. DOI: 10.1101/gr.6743907

53. Smit AR, Hubley R, Green P (2013) RepeatMasker Open-4.0. http:// www.repeatmasker.org.

54. Keller O, Kollmar M, Stanke M, Waack S (2011) A novel hybrid gene prediction method employing protein multiple sequence alignments. Bioinformatics 27(6):757-763. doi:

10.1093/bioinformatics/btr010.

55. Ter-Hovhannisyan V, Lomsadze A, Chernoff Y, Borodovsky M (2008) Gene prediction in novel fungal genomes using an ab initio algorithm with unsupervised training. Genome Research 18:1979-1990. doi: 10.1101/gr.081612.108.

56. Zaharia M, Bolosky WJ, Curtis K, Fox A, Patterson D, Shenker S, Stoica I, Karp RM, Sittler T (2011) Faster and More Accurate Sequence Alignment with SNAP. arXiv:1111.5572v1.

57. Lowe TM, Eddy SR (1997) tRNAscan-SE: a program for improved detection of transfer RNA genes in genomic sequence. Nucleic Acids Research 25:955-964. PMCID: PMC146525. DOI: 10.1093/nar/25.5.955.

58. Camacho C, Coulouris G, Avagyan V, Ma N, Papadopoulos J, Bealer K, Madden TL (2009) BLAST+: architecture and applications. BMC Bioinformatics 10:421-429. doi.org/10.1186/1471-2105-10-421.

59. Jones P, Binns D, Chang H, Fraser M, Li W, McAnulla C, McWilliam H, Maslen J, Mitchell A, Nuka G, Pesseat S, Quinn AF, Sangrador-Vegas A, Scheremetjew M, Yong S, Lopez R, Hunter S. 2014. InterProScan 5: genome-scale protein function classification. Bioinformatics. 30(9):1236-40. doi: 10.1093/bioinformatics/btu031.

60. Zhang H, Yohe T, Huang L, Entwistle S, Wu P, Yang Z, Busk PK, Xu Y, Yin Y (2018) dbCAN2: a meta server for automated carbohydrate-active enzyme annotation. Nucleic Acids Research 46:W95-W101. DOI: 10.1093/nar/gky418.

61. Urban M, Cuzick A, Seager J, Wood V, Rutherford K, Venkatesh SY, De Silva N, Martinez MC, Pedro H, Yates AD, Hassani-Pak K, Hammond-Kosack KE (2020) PHI-base: the pathogen-host interactions database. Nucleic Acids Research. 48: D613-D620. https://doi.org/10.1093/nar/gkz904.

62. Blin K, Shaw S, Steinke K, Villebro R, Ziemert N, Lee SY, Medema MH, Weber T (2019) antiSMASH 5.0: updates to the secondary metabolite genome mining pipeline. Nucleic Acids Research. Volume 47, Issue W1:W81-W87. doi.org/10.1093/nar/gkz310.

63. Almagro Armenteros JJ, Sønderby CK, Sønderby SK, Nielsen H, Winther O (2017) DeepLoc: prediction of protein subcellular localization using deep learning. Bioinformatics. 33:3387-3395. doi: 10.1093/bioinformatics/btx431.

64. Soderlund C, Nelson W, Shoemaker A, Paterson A (2006) SyMAP: A System for Discovering and Viewing Syntenic Regions of FPC maps. Genome Research 16:1159-1168. DOI: 10.1101/gr.5396706. 
65. Soderlund C, Bomhoff M, Nelson W (2011) SyMAP: A turnkey synteny system with application to plant genomes. Nucleic Acids Research 39(10):e68. doi.org/10.1093/nar/gkr123.

66. Xu L, Dong Z, Fang L, Luo Y, Wei Z, Guo H, Zhang G, Gu YQ, Coleman-Derr D, Xia Q, Wang Y (2019) OrthoVenn2: a web server for whole-genome comparison and annotation of orthologous clusters across multiple species. Nucleic Acids Research. 47:W52-W58. DOI: 10.1093/nar/gkz333.

67. Rehner SA, Buckley E. 2005. A Beauveria phylogeny inferred from nuclear ITS and EF1-a sequences: evidence for cryptic diversification and links to Cordyceps teleomorphs. Mycologia. 97:84-98. DOI: 10.3852/mycologia.97.1.84

68. White TJ, Bruns T, Taylor J (1990) Amplification and direct sequencing of fungal ribosomal RNA genes for phylognetics. In: A Guide to Molecular Methods and Applications (Innis MA, Gelfand DH, Sninsky JJ, White JW, eds). Academic Press, New York: 315-322. dx.doi.org/10.1016/B978-0-12372180-8.50042-1.

69. Walters W, Hyde ER, Berg-Lyons D, Ackermann G, Humphrey G, Parada A, Gilbert JA, Jansson JK, Caporaso JG, Fuhrman JA, Apprill A, Knight B (2015) Improved bacterial 16S rRNA gene (V4 and V4$5)$ and fungal internal transcribed spacer marker gene primers for microbial community surveys. mSystems 1(1):e00009-15. doi: 10.1128/mSystems.00009-15.

70. Bolger AM, Lohse M, Usadel B (2014) Trimmomatic: A flexible trimmer for Illumina Sequence Data. Bioinformatics. 30:2114-2120. doi.org/10.1093/bioinformatics/btu170

71. Schloss PD, Westcott SL, Ryabin T, Hall JR, Hartmann M, Hollister EB, Lesniewski RA, Oakley BB, Parks DH, Robinson CJ, Sahl JW, Stres B, Thallinger GG, Van Horn DJ, Weber CF (2009) Introducing mothur: Open-source, platform-independent, community-supported software for describing and comparing microbial communities. Applied and Environmental Microbiology. 75:7537-7541. dx.doi.org/10.1128/AEM.01541-09.

72. Kozich JJ, Westcott SL, Baxter NT, Highlander SK, Schloss PD (2013) Development of a Dual-Index Sequencing Strategy and Curation Pipeline for Analyzing Amplicon Sequence Data on the MiSeq Illumina Sequencing Platform. Applied and Environmental Microbiology. 79:5112-5120. doi:10.1128/AEM.01043-13.

73. Edgar RC, Haas BJ, Clemente JC, Quince C, Knight R (2011) UCHIME improves sensitivity and speed of chimera detection. Bioinformatics. 27:2194-200. doi.org/10.1093/bioinformatics/btr381.

74. Edgar RC (2010) Search and clustering orders of magnitude faster than BLAST. Bioinformatics. 26(19):2460-2461. https://doi.org/10.1093/bioinformatics/btq461.

75. Quast C, Pruesse E, Yilmaz P, Gerken J, Schweer T, Yarza P, Peplies J, Glöckner FO (2013) The SILVA ribosomal RNA gene database project: improved data processing and web-based tools. Nucleic Acid Res.41:D590-D596. DOI: 10.1093/nar/gks1219.

76. Nilsson RH, Larsson K-H, Taylor AFS, Bengtsson-Palme J, Jeppesen JS, Schigel D, Kennedy P, Picard K, Glöckner FO, Tedersoo L, Saar I, Kõljalg U, Abarenkov K (2019) The UNITE database for molecular identification of fungi: handling dark taxa and parallel taxonomic classifications. Nucleic Acids Research. 47:D259-D264. doi: 10.1093/nar/gky1022. 
77. Wang Q, Garrity GM, Tiedje JM, Cole JR (2007) Naïve Bayesian classifier for rapid assignment of rRNA sequences into the new bacterial taxonomy. Applied and Environmental Microbiology. 73: 5261-5267. DOI: 10.1128/AEM.00062-07.

78. Oksanen J, Blanchet FG, Friendly M, Kindt R, Legendre P, McGlinn D, Minchin PR, O'Hara RB, Simpson GL, Solymos P, Stevens MHH, Szoecs E, Wagner H (2017) vegan: Community Ecology Package. R package version 2.4-2.

79. Olofsson TC, Vásquez A (2008) Detection and identification of a novel lactic acid bacterial flora within the honey stomach of the honeybeeApis mellifera. Current Microbiology. 57:356-363. DOI: 10.1007/s00284-008-9202-0.

80. Hill TCJ, Walsh KA, Harris JA, Moffett BF (2006) Using ecological diversity measures with bacterial communities. FEMS Microbiology Ecology. 43:1-11. doi.org/10.1111/j.1574-6941.2003.tb01040.x.

81. Nagendra $\mathrm{H}$ (2002) Opposite trends in response to Shannon and Simpson indices of landscape diversity. Applied Geography. 22:175-186. dx.doi.org/10.1016/S0143-6228(02)00002-4.

82. Zhang H, John R, Peng Z, Yuan J, Chu C, Du G, Zhou S (2012) The relationship between species richness and evenness in plant communities along a successional gradient: A study from sub-alpine meadows of the eastern Qinghai-Tibetan Plateau, China. PLoS ONE 7:e49024. DOI: 10.1371/journal.pone.0049024.

83. Paulson JN, Talukder H, Pop M, Bravo HC (2021) metagenomeSeq: Statistical analysis for sparse high-throughput sequencing. Bioconductor package: 1.16.0.

84. Wickham H (2016) ggplot2: Elegant Graphics for Data Analysis. Springer-Verlag New York. ISBN 9783-319-24277-4. https://ggplot2.tidyverse.org.

85. Santana MF, Queiroz MV (2015) Transposable Elements in Fungi: A Genomic Approach. Scientific Journal of Genetics and Gene Therapy 1(1):012-016.

86. Coleman JJ, Mylonakis E (2009) Efflux in Fungi: La Pièce de Résistance. PLoS Pathogens 5(6): e1000486. https://doi.org/10.1371/journal.ppat.1000486.

87. Macheleidt J, Mattern DJ, Fischer J, Netzker T, Weber J, Schroeckh V, Valiantem V, Brakhage AA (2016) Regulation and Role of Fungal Secondary Metabolites. Annual Review of Genetics 50:371392. DOI: 10.1146/annurev-genet-120215-035203.

88. Syed K, Yadav JS (2012) P450monooxygenases (P450ome) of the model white rot fungus Phanerochaete chrysosporium. Critical Reviews in Microbiology 38(4):339-363. doi: 10.3109/1040841X.2012.682050.

89. Ichinose H (2013) Cytochrome P450 of wood-rotting basidiomycetes and biotechnological applications. Biotechnology and Applied Biochemistry. 60:71-81. DOI: 10.1002/bab.1061.

90. Qhanya LB, Matowane G, Chen W, Sun Y, Letsimo EM, Parvez M, Yu J-H, Mashele SS, Syed K (2015) Genome-Wide Annotation and Comparative Analysis of Cytochrome P450 Monooxygenases in Basidiomycete Biotrophic Plant Pathogens. PLOS ONE. 10(11):e0142100. doi.org/10.1371/journal.pone.0142100. 
91. Durairaj P, Hur J-S, Yun H (2016) Versatile biocatalysis of fungal cytochrome P450 monoxygenases. Microbial Cell Factories. 15:125. doi.org/10.1186/s12934-016-0523-6.

92. Gonçalves AP, Heller J, Daskalov A, Videra A, Glass NL (2017) Regulated forms of cell death in fungi. Frontiers in Microbiology 8:1837. doi.org/10.3389/fmicb.2017.01837.

93. Schmidt-Dannert C (2014) Biosynthesis of terpenoid natural products in fungi. In: Schrader J., Bohlmann J. (eds) Biotechnology of Isoprenoids. Advances in Biochemical Engineering/Biotechnology, vol 148. Springer, Cham. DOI: 10.1007/10_2014_283.

94. Quin MB, Flynn CM, Schmidt-Dannert C (2014) Traversing the fungal terpenome. Natural Product Reports 31(10):1449-1473. doi: 10.1039/c4np00075g.

95. Shaw CG III, Roth L (1978). Control of Armillaria root rot in managed coniferous forests. European Journal of Forest Pathology. 8:163-174. doi.org/10.1111/j.1439-0329.1978.tb01463.x.

96. Coetzee MPA, Wingfield BD, Wingfield MJ (2018) Armillaria root-rot pathogens: Species boundaries and global distribution. MDPI Pathogens 7:83. https://doi.org/10.3390/pathogens7040083

97. Burdsall HH, Volk, TJ (2008) Armillaria solidipes, an older name for the fungus called Armillaria ostoyae. North American Fungi. 3:261-267. DOI: http://dx.doi.org/10.2509/naf2008.003.00717.

98. Presti LL, Lanver D, Schweizer G, Tanaka S, Liang L, Tollot M, Zuccaro A, Reissmann S, Kahmann R (2015) Fungal effectors and plant susceptibility. Annual Review of Plant Biology 66:513-545. doi.org/10.1146/annurev-arplant-043014-114623.

99. Kim K, Jeon J, Choi J, Cheong K, Song H, Choi G, Kang S, Lee Y (2016) Kingdom-wide analysis of fungal small secreted proteins (SSPs) reveals their potential role in host association. Frontiers in Plant Science. 7:186. doi: 10.3389/fpls.2016.00186.

100. Zhao Z, Liu H, Wang C, Xu J-R (2013) Comparative analysis of fungal genomes reveals different plant cell wall degrading capacity in fungi. BMC Genomics 14:274-288. doi.org/10.1186/1471-216414-274.

101. Krijger J-J, Thon MR, Deising HB, Wirsel SGR (2014) Compositions of fungal secretomes indicate a greater impact of phylogenetic history than lifestyle adaptation. BMC Genomics 15:722-739. doi.org/10.1186/1471-2164-15-722.

102. Varrot A, Basheer SM, Imberty A (2013) Fungal lectins: structure, function and potential applications. Current Opinion in Structural Biology 23:678-685. http://dx.doi.org/10.1016/j.sbi.2013.07.007 .

103. Sahu N, Merényi Z, Bálint B, Kiss B, Sipos G, Owens R, Nagy LG (2020) Hallmarks of basidiomycete soft- and white-rot in wood-decay-omics data of Armillaria. bioRxiv 2020.05.04.075879; doi.org/10.1101/2020.05.04.075879.

104. Neuwald AF, Aravind L, Altschul SF (2018) Inferring joint sequence-structural determinants of protein functional specificity. eLIFE 7:e29880. doi.org/10.7554/eLife.29880.001.

105. Palma-Guerrero J, Ma X, Torriani SFF, Zala M, Francisco CS, Hartmann FE, Croll D, McDonald BA (2017) Comparative Transcriptome Analyses in Zymoseptoria tritici Reveal Significant Differences in Gene Expression Among Strains During Plant Infection. Molecular Plant-Microbe Interactions. 30:231-244. doi.org/10.1094/MPMI-07-16-0146-R. 
106. Kimura M, Takai T, Takahashi-Ando N, Ahsato S, Fujimura M (2007) Molecular and genetic studies of Fusarium trichothecene biosynthesis: pathoways, genes, and evolution. Bioscience, Biotechnology, and Biochemistry. 71:1-19. DOI: 10.1271/bbb.70183.

107. Schmidt R, Etalo DW, de Jager V, Gerards S, Zweers H, de Boer W, Garbeva P (2016) Microbial Small Talk: Volatiles in Fungal-Bacterial Interactions. Frontiers in Microbiology 6:1495. doi.org/10.3389/fmicb.2015.01495.

108. Deveau A, Bonito G, Uehling J, Paoletti M, Becker M, Bindschedler S, Hacquard S, Hervé V, Labbé J, Lastovetsky OA, Mieszkin S, Millet LJ, Vajna B, Junier P, Bonfante P, Krom BP, Olsson S, Dirk van Elsas J, Wick, LY (2018) Bacterial-fungal interactions: ecology, mechanisms and challenges. FEMS Microbiology Reviews. 42:335-352. doi: 10.1093/femsre/fuy008.

109. Huang AC, Osbourn A (2019) Plant terpenes that mediate below-ground interactions: prospects for bioengineering terpenoids for plant protection. Pest Management Science. 75:2368-2377. doi: 10.1002/ps.5410.

110. Farh ME, Jeon J (2020) Roles of fungal volatiles from perspective of distinct lifestyles in filamentous fungi. The Plant Pathology Journal. 36:193-203. doi:10.5423/PPJ.RW.02.2020.0025.

111. Proctor RH, McCormick SP, Kim H, Cardoza RE, Stanley AM, Lindo L, Kelly A, Brown DW, Lee T, Vaughan MM, Alexander NJ, Busman M, Gutiérrez S (2018) Evolution of structural diversity of trichothecenes, a family of toxins produced by plant pathogenic and entomopathogenic fungi. PloS Pathogens. 14(4):e1006946. doi.org/10.1371/journal. ppat.1006946.

112. Holmes AJ, Tujula NA, Holley M, Contos A, James JM, Rogers P, Gillings MR (2001) Phylogenetic structure of unusual aquatic microbial formations in Nullarbor caves, Australia. Environmental Microbiology. 3:256-264. DOI: 10.1046/j.1462-2920.2001.00187.x.

113. Schabereiter-Gurtner C, Saiz-Jimenez C, Piñar G, Lubitz W, Rölleke S (2002) Phylogenetic 16S rRNA analysis reveals the presence of complex and partly unknown bacterial communities in Tito Bustillo cave, Spain, and on its Paleolithic paintings. Environmental Microbiology. 4:392-400. DOI: 10.1046/j.1462-2920.2002.00303.x.

114. Zhu H-Z, Zhang ZF, Zhou N, Jiang CY, Wang BJ, Cai L, Liu S-J (2019) Diversity, distribution and cooccurrence patterns of bacterial communities in a karst cave system. Frontiers in Microbiology. 10: 1726. doi.org/10.3389/fmicb.2019.01726.

115. Sjöberg S, Stairs CW, Allard B, Homa F, Martin T, Sjöberg V, Ettema TJG, Dupraz C. (2020) Microbiomes in a manganese oxide producing ecosystem in the Ytterby mine, Sweden: impact on metal mobility. FEMS Microbiology Ecology. 96: doi.org/10.1093/femsec/fiaa169.

116. Barriuso J, Márin S, Mellado RP (2010) Effects of the herbicide glyphosate-tolerant maize rhizobacteria communities: a comparison with pre-emergency applied herbicide consisting of a combination of acetochlor and terbuthylazine. Environmental Microbiology. 12:1021-1030. DOI: 10.1111/j.1462-2920.2009.02146.x.

117. Bian X, Xiao S, Zhao Y, Xu Y, Yang H, Zhang L (2020) Comparative analysis of rhizosphere soil physiochemical characteristics and microbial communities between rusty and healthy ginseng root. 
Scientific Reports. 10:15756. doi.org/10.1038/s41598-020-71024-8.

118. Nusslein K, Tiedje JM (1999) Soil bacterial community shift correlated with change from forest to pasture vegetation in a tropical soil. Applied and Environmental Microbiology. 65:3622-3626. DOI:10.1128/AEM.65.8.3622-3626.1999.

119. Köberl M, Dita M, Martinuz A, Staver C, Berg G (2017) Member of Gammaproteobacteria as indicator species of healthy banana plants on Fusarium wilt-infested fields in Central America. Scientific Reports. 7:45318. doi.org/10.1038/srep45318.

120. Byers A-K, Condron L, O'Callaghan M, Waipara N, Black A (2020) Soil microbial community restructuring and functional changes in ancient kauri (Agathis australis) forest impacted by the invasive pathogen Phytophthora agathidicida. Soil Biology and Biochemistry. 150:108016. https://doi.org/10.1016/j.soilbio.2020.108016.

121. Przemieniecki SW, Damszel M, Ciesielski S, Kubiak K, Mastalerz J, Sierota Z, Gorczyca A (2021) Bacterial microbiome in Armillaria ostoyae rhizomorphs inhabiting the root zone during progressively dying Scots pine. Applied Soil Ecology. 164:103929. doi.org/10.1016/j.apsoil.2021.103929.

122. Saccá ML, Manici LM, Caputo F, Frisullo S (2019) Changes in rhizosphere bacterial communities associated with tree decline: grapevine esca syndrome case study. Canadian Journal of Microbiology. 65:930-943. doi.org/10.1139/cjm-2019-0384.

123. Liu J, He X, Sun J, Ma Y (2021) A degeneration gradient of poplar trees contributes to the taxonomic, functional, and resistome diversity of bacterial communities in rhizosphere soils. International Journal of Molecular Sciences. 22:3438. doi.org/10.3390/ijms22073438.

124. Tong A-Z, Liu W, Liu Q, Xia G-Q, Zhu J-Y (2021) Diversity and composition of the Panax ginseng rhizosphere microbiome in various cultivation modes and ages. BMC Microbiology. 21: 18. https://doi.org/10.1186/s12866-020-02081-2.

125. Balestrini R, Lumini E, Borriello R, Biancotto V (2014) Plant-soil biota interactions. In: E.A. Paul (4th ed.), Soil Microbiology, Ecology, and Biochemistry. Cambridge, MA: Academic Press. p. 311-338. eBook ISBN: 9780123914118. https://doi.org/10.1016/C2011-0-05497-2.

126. Horton BW, Glen M, Davidson NJ, Ratkowsky D, Close DC, Wardlaw TJ, Mohammed C (2013) Temperate eucalypt forest decline is linked to altered mycorrhizal communities mediated by soil chemistry. Forest Ecology and Management. 302:329-337. DOI: 10.1016/j.foreco.2013.04.006.

127. Kipfer T, Egli S, Ghazoul J, Moser B, Wohlgemuth T (2010) Susceptibility of ectomycorrhizal fungi to soil heating. Fungal Biology. 114: 467-472. doi: 10.1016/j.funbio.2010.03.008.

128. Rudawska M, Leski T, Stasinska M (2011) Species and functional diversity of ectomycorrhizal fungal communities on Scots pine (Pinus sy/vestris L.) trees on three different sites. Annual of Forest Science. 68: 5-15. DOI:10.1007/s13595-101-0002-x.

\section{Figures}




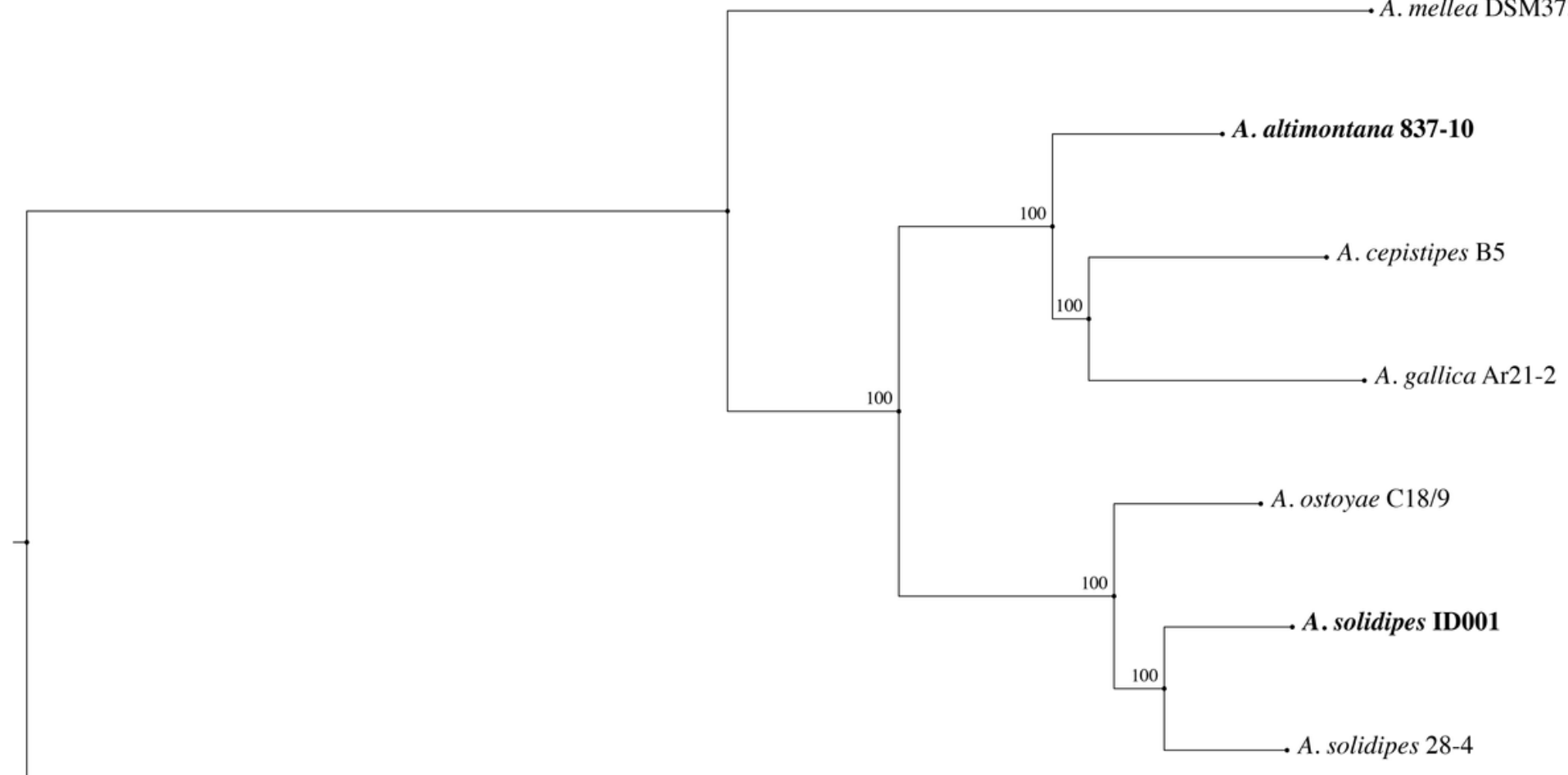

- A. fuscipes CMW2740

\section{Figure 1}

Whole genome phylogenetic tree of Armillaria species: Armillaria mellea DSM3731 [France], A. altimontana 837-10 [Idaho], A. cepistides B5 [Italy], A. gallica Ar21-2 [Vermont], A ostoyae C18/9 [Switzerland], A. solidipes ID001 [Idaho], and A. solidipes 28-4 [Vermont].
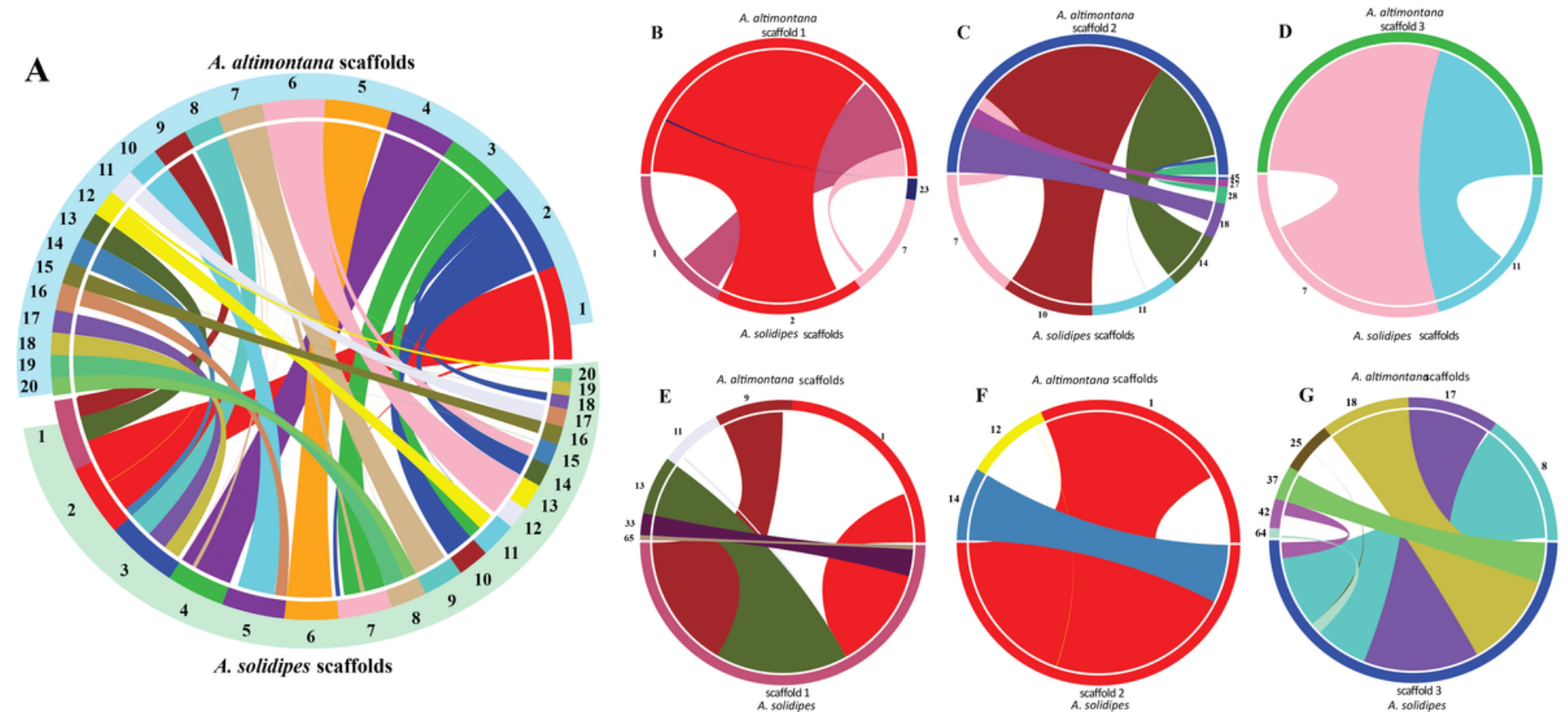

Figure 2 
Blocks of synteny comparing the 20 largest scaffolds of each Armillaria species (A); B-D: block of synteny of the three largest A. altimontana scaffolds with A. solidipes scaffolds; E-G: blocks of synteny of the three largest A. solidipes scaffolds with A. altimontana scaffolds.

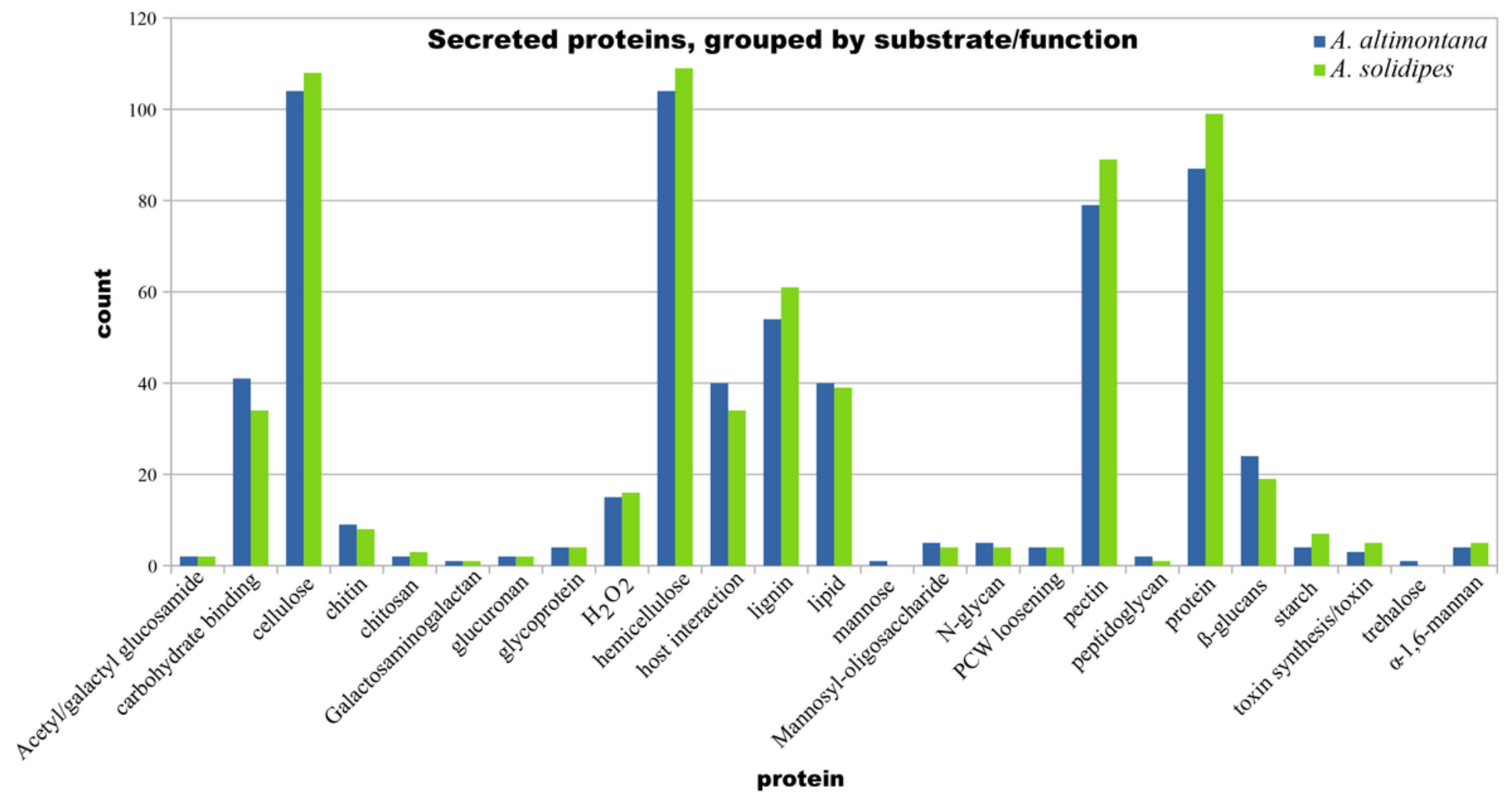

Figure 3

Comparison of the number of pathogenicity-related secreted proteins in Armillaria altimontana and A. solidipes, grouped by function. Small secreted proteins are not included. All CBM genes were considered with a "carbohydrate binding" function. 


\section{A. Comparison of proteins}

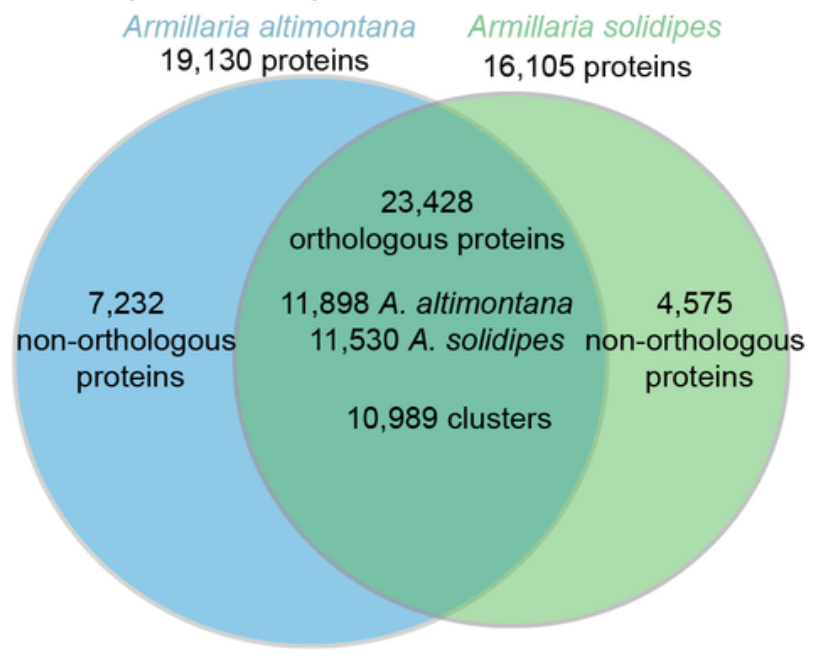

B. Comparison of bacterial communities

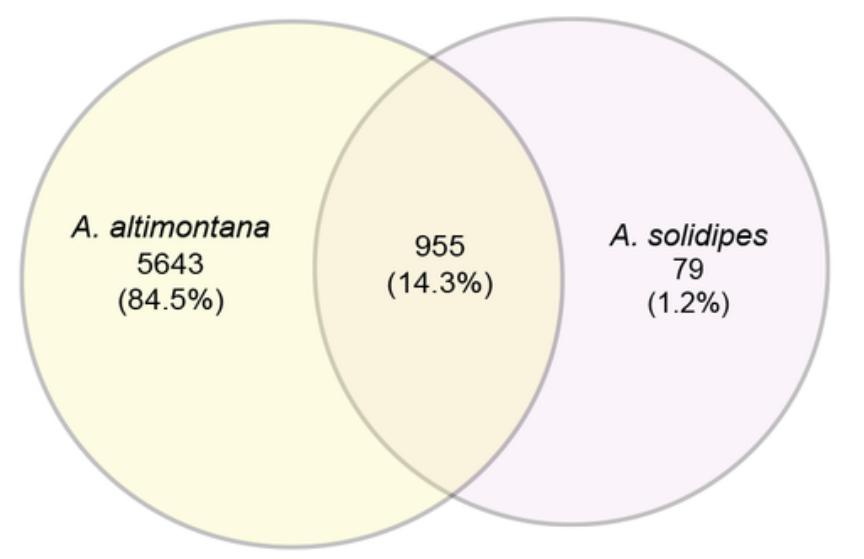

C. Comparison of fungal communities

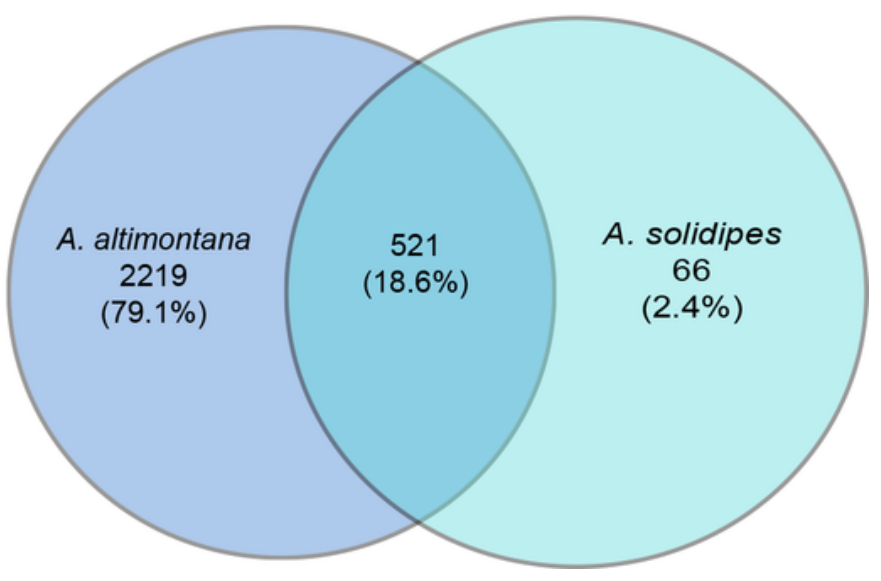

\section{Figure 4}

A. Orthologous and non-orthologous proteins of the two Armillaria species. Microbial communities (OTUs) between A. altimontana and A. solidipes. 4 B,C. Core microbiome encompasses overlap between both species, while unique OTUs occur within each circle for B. Unique OTUs occur within each of the three circles; 4B. bacterial communities. C. Fungal communities. 


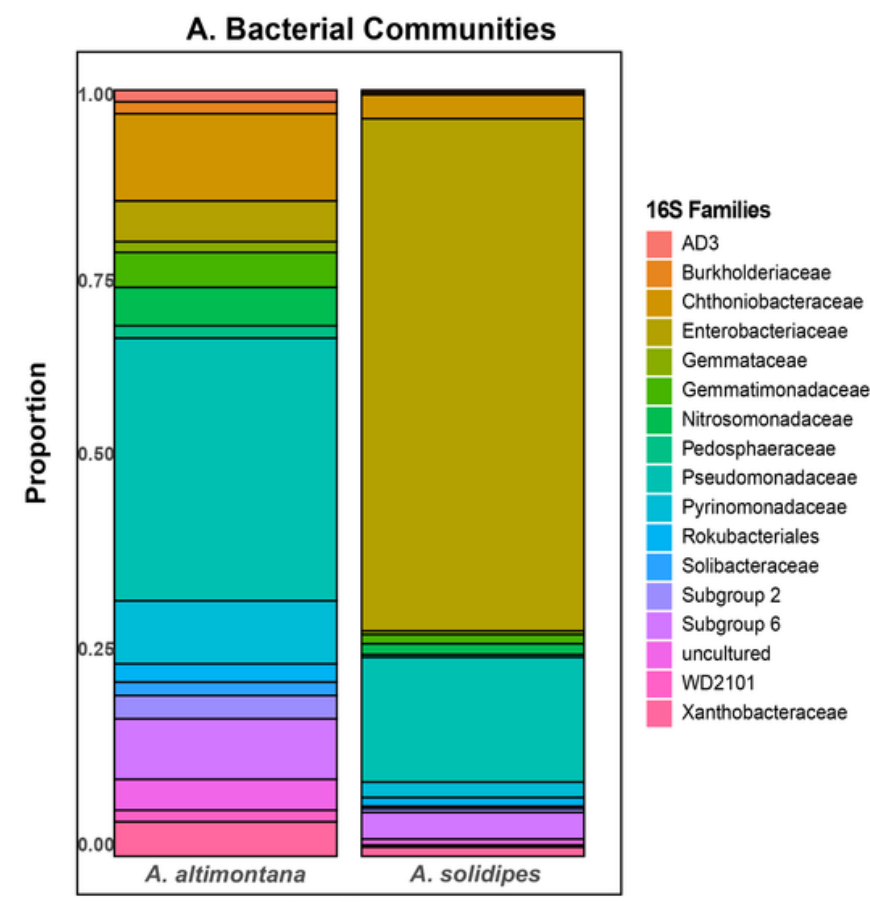

Armillaria

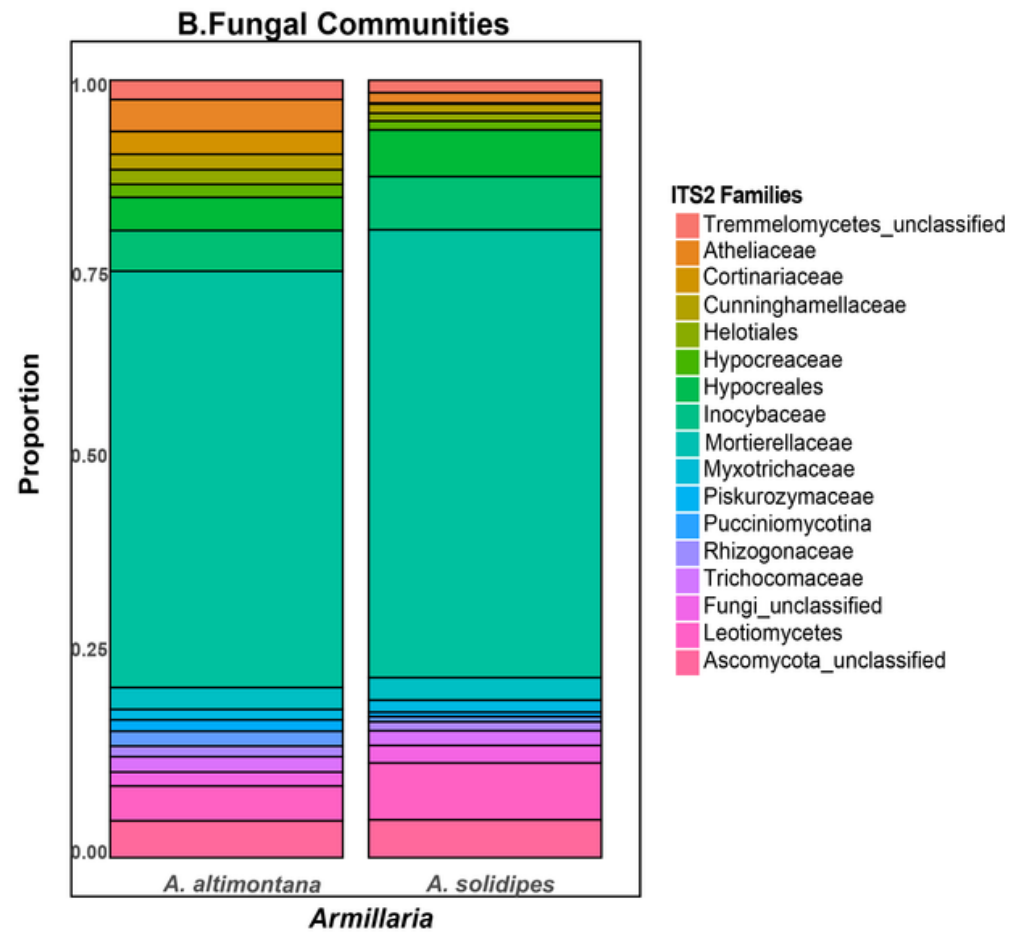

Figure 5

Stacked bar graphs of top 17 most abundant bacterial families (A) and fungal families (B) for Armillaria altimontana and A. solidipes. 


\section{A. Signficant Bacterial Communities (90\%)}

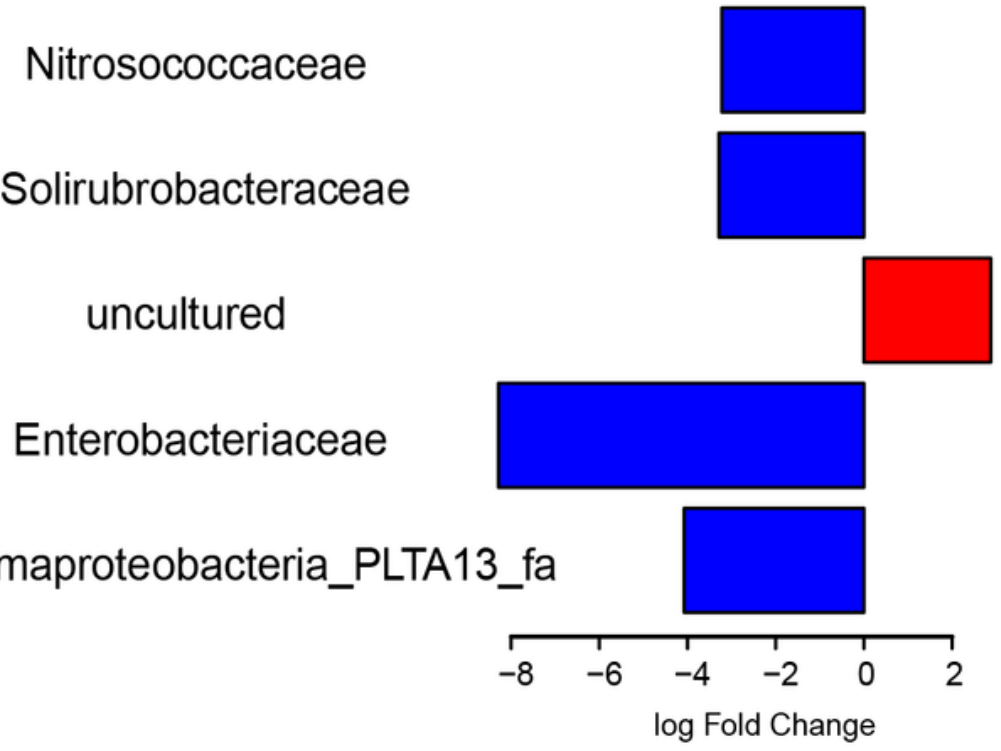

\section{B. Signficant Fungal Communities (90\%)}

Fungi_unclassified

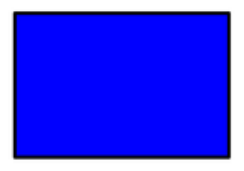

Fungi_unclassified

Suillaceae

Rhizopogonaceae
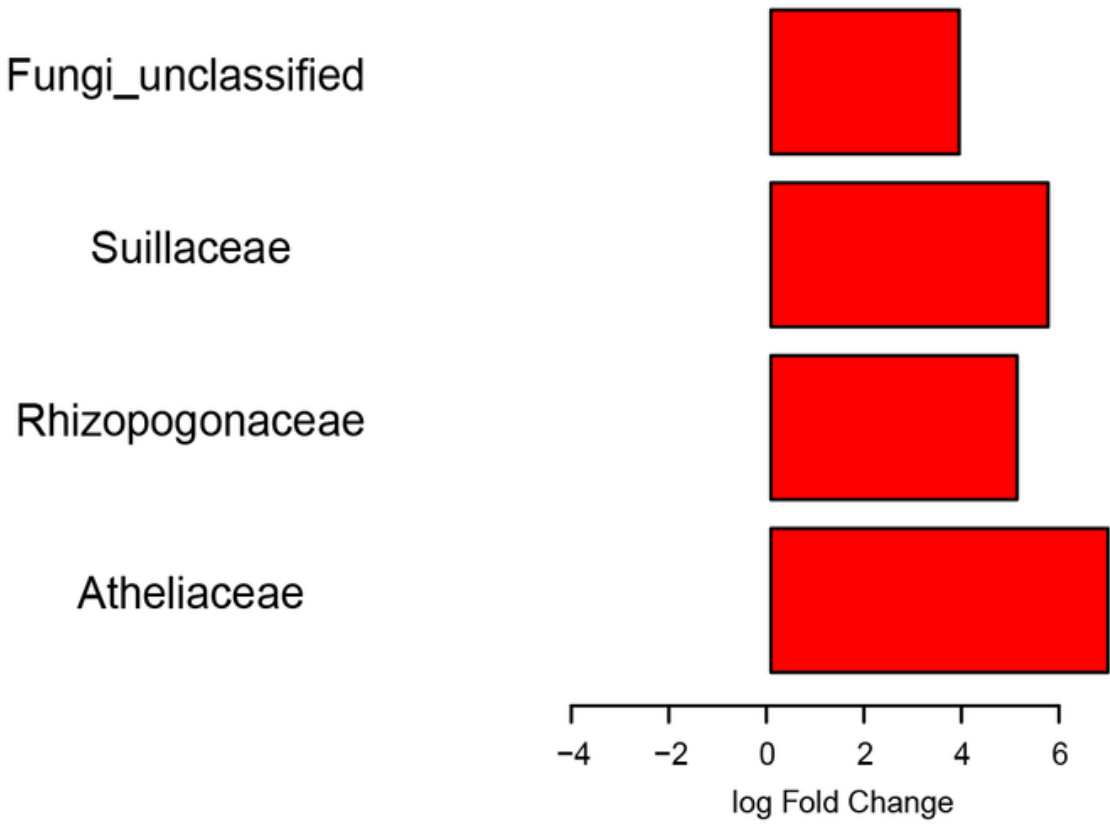

Figure 6

Log fold change for unique bacterial (A) and Fungal (B) OTUs in association between A. altimontana (red) and A. solidipes (blue). Significance is based on $90 \%$ confidence log fold change between both species of Armillaria.

\section{Supplementary Files}


This is a list of supplementary files associated with this preprint. Click to download.

- SupplementalTables.docx

- SupplementalFigure1.pdf

- SupplementalFigure2secretedproteinsbothhorizontalnoGH0.pdf

- SupplementalFigure3nonsecretedcazymesgrouped.pdf

- SupplementalFigure4abRarefractions.pdf

- SupplementalFigure5PCoA16SITS.pdf 